\title{
Linking functional with personal income distribution: A stock-flow consistent approach
}

\author{
Yannis Dafermos $^{1 *}$ and Christos Papatheodorou ${ }^{2}$
}

${ }^{1}$ Department of Accounting, Economics and Finance, University of the West of England, Bristol, UK

${ }^{2}$ Department of Social Administration and Political Science, Democritus University of Thrace, Komotini, Greece

\begin{abstract}
This paper develops a benchmark stock-flow consistent model that links functional with personal income distribution. The model consists of various household groups that receive income from different sources or from the same sources in different proportions. The dynamic linkage between functional and personal income distribution is formulated as part of a complete macroeconomic system. Inequality decomposition techniques are employed to associate income sources with personal income distribution. Simulation exercises are conducted to reveal the various ways through which functional and personal income distribution interact. In the simulations a rise in the exogenous component of low-skilled workers' wage share reduces inequality in the short run; in the medium to long run inequality starts increasing due to certain macroeconomic developments, but remains lower than its initial level in almost all cases. A change in functional income distribution due to a rise in the dividend payout ratio of firms increases inequality both in the short run and the long run.
\end{abstract}

JEL Classification: D31; D33; E10

Keywords: functional income distribution; personal income distribution; stock-flow consistent modelling

Acknowledgements: Earlier versions of this paper were presented at the 15th Conference of the Research Network Macroeconomics and Macroeconomic Policies (FMM), Berlin, 28-29 October, 2011 and the 25th Conference of the European Association for Evolutionary Political Economy (EAEPE), Paris, 7-9 November, 
2013. We wish to thank the conference participants, and especially Malcolm Sawyer and Edward Wolff, for useful feedback. Constructive comments from two anonymous referees are also gratefully acknowledged. The usual disclaimers apply.

*Corresponding author. Email: Yannis.Dafermos@uwe.ac.uk 


\section{Linking functional with personal income distribution:}

\section{A stock-flow consistent approach}

\section{Introduction}

The distribution of income is traditionally a core issue in economic theory and policy analysis. So far, economists have mostly focused on two types of income distribution: the distribution among the factors of production (functional income distribution) and the distribution among the members of the society (personal income distribution). However, the vast majority of the existing theoretical frameworks examines these two types of income distribution separately. There is still a lack of an integrated framework that connects income inequality at the micro level with factor shares at the macro level.

The absence of such a framework does not square with the fact that people in different income brackets receive income from different sources (labour, interest, distributed profits etc.) or from the same sources in different proportions. From this it follows that any change in functional income distribution has non-trivial effects on the way that income is distributed among the members of the society. The absence of such a framework is also at odds with the findings of various empirical works in which significant links between functional and personal income distribution are documented. As Atkinson (2009) points out, our understanding of inequalities could substantially be enhanced if the macro and the micro perspectives on income distribution were to be unified. 
This paper argues that the stock-flow consistent (SFC) approach to macroeconomic modelling can provide the appropriate analytical platform for linking functional with personal income distribution. The SFC approach can be traced back to the works of the Cambridge Economic Policy Group (see e.g. Cripps and Godley 1976) and the Yale group of James Tobin (see e.g. Backus et al. 1980; Tobin 1982). Although this approach was largely sidetracked from the mid 1980s to the late 1990s, it has gained a resurgence of interest over the last decade or so largely due to the works of Wynne Godley and Marc Lavoie (see, for instance, Lavoie and Godley 2001-2; Godley and Lavoie 2007).

The defining feature of the SFC approach is the explicit integration of accounting into dynamic macro modelling. In SFC models the stocks (deposits, equities, loans etc.) and the flows (interest, profits, wages etc.) of the institutional sectors of the macroeconomy are explicitly depicted via balance sheet and transactions matrices. This allows an integrated consideration of the macro implications of stock-flow consistency. It also allows a detailed analysis of the links between the financial and the real spheres of the economy as well as between income and wealth.

There are three reasons why the stock-flow consistent framework is an appropriate platform for the analysis of the links between functional and personal income distribution. First, the formulation of the connections between functional and personal income distribution requires the separation of the household sector into various groups, which are characterised by different income sources and balance sheet structures. The complex stock-flow interactions between these groups and the other sectors of the economy (e.g. firms, banks and the government) need to be rigorously modelled if the analysis is to be consistent and illuminating. The SFC framework ensures such a coherent modelling. 
Second, the dynamic interaction between income and wealth plays a major role in the way that functional income distribution affects personal income inequality. Households with more wealth typically receive income from more sources than households with less wealth. Hence, the more unequal the allocation of wealth the more personal income distribution is responsive to changes in the wealth-related income sources (such as interest or profits). Furthermore, any change in factor shares affects in a heterogeneous way the savings of households, modifying the distribution of wealth and, hence, the distribution of personal income. The crucial role of the interconnected trajectories in which wealth and income evolve can successfully be considered within an SFC framework.

Third, functional income distribution dynamically interacts with personal income distribution through the macroeconomic system. This interaction takes place in two stages. In the first stage, both types of income distribution affect macroeconomic activity. Functional income distribution influences consumption, because of the different propensities to consume out of different types of income; it also influences investment primarily due to its impact on profitability and the utilisation rate. ${ }^{1}$ Personal income distribution affects consumption expenditures since the same source of income is likely to be distributed to households with different propensities to consume (see Carvalho and Rezai 2014; Palley 2015). In the second stage, distribution-induced changes in economic activity influence the bargaining power of workers in the wage-setting procedure and the ability of firms to increase the prices of their products, with profound effects on the income distribution between wages and profits; they also influence the proportion of households that receive income from unemployment benefits and, potentially, the distribution of the wage bill among households. SFC modelling provides a platform for the direct incorporation of all the above-mentioned effects. 
The purpose of this paper is to use the SFC approach in order to develop a benchmark framework that links functional with personal income distribution through the interaction of heterogeneous stocks and flows. In our framework income inequality is reflected in the way that income is distributed among certain household groups with heterogeneous skills, wealth and income sources. Functional distribution is captured by the way that income is distributed between factors (wages, profits, unemployment benefits and interest).

The paper is organised as follows. Section 2 provides a brief review of the related literature. Section 3 lays out the theoretical model. Section 4 presents the inequality indices utilised in the model and describes the source-decomposition procedure, which allows us to link functional with personal income distribution. Section 5 provides the results of our simulation exercises designed to illustrate the various ways through which functional and personal income distribution interact in our benchmark model. Section 6 summarises and concludes.

\section{Links between functional and personal income distribution: A brief review of the literature}

The effects of functional income distribution on personal income distribution have been investigated in many empirical studies. The majority of these studies explores these effects employing inequality decomposition techniques that permit the estimation of the income sources’ contribution to total income inequality (see e.g. Jenkins 1995; Jännti 1997; Papatheodorou 1998; Fräßdorf, Grabka and Schwarze 2011; OECD 2011; García-Peñalosa and Orgiazzi 2013; Wolff and Zacharias 2013). Although the results differ across countries and time periods, some common findings are the important contribution of capital and self- 
employment income to total inequality, the equalising role of social transfers and taxes and the significant effects of wage inequality on total inequality.

The influence of functional on personal income distribution has also been examined in studies that use econometric techniques. Employing a sample of developed and developing countries, Daudey and García-Peñalosa (2007) find that a higher labour income share is associated with lower inequality. A similar result is reported by Checchi and García-Peñalosa (2010) for a panel of OECD countries. Schlenker and Schmid (2013) utilise data for EU countries and find that personal income distribution depends significantly on capital income shares.

A novel empirical analysis of the links between functional and personal income distribution (without the use of econometrics) is provided by Piketty (2014). Employing a new historical dataset that covers many economies and a very long period of time, he argues that changes in the capital income share are among the principal drivers of the evolution of inequality in the long run. This primarily stems from the fact that capital income is traditionally much more unequally distributed than labour income.

Despite this empirical evidence, the theoretical models on the link between functional and personal income distribution are rare. Dagum (1999), Checchi and García-Peñalosa (2010) and Palley (2015) are some exceptions. Dagum (1999) puts forward a non-linear income generating function according to which economic units' income depends on their human capital and wealth. Utilising this function as a basis for his analysis, he provides a theoretical framework for the joint examination of functional and personal income distribution. Checchi and García-Peñalosa (2010) develop a model in which the economy is composed of four types of agents: unemployed, unskilled workers, skilled workers that receive no capital income, and 
skilled workers that receive both labour and capital income. The Gini coefficient is suitably formulated to express personal income inequality as a function of the labour share (and various other factors). In their static framework, a rise in the labour share has opposing effects on inequality: on the one hand, it tends to reduce it by narrowing the income differential between capital and non-capital owners; on the other hand, it tends to increase it by raising the income gap between employed and unemployed agents. Palley (2015) develops a neoKaleckian-Goodwin model with three classes: workers, a middle-management middle class and a top management capitalist class. Personal income distribution is captured by the distribution of wage income between workers and middle managers. Functional and personal income distributions are linked since the latter is postulated to depend on the employment rate and the capacity utilisation rate, both of which rely on functional income distribution.

The theoretical model of this paper is closer in spirit to Palley's model in which (contrary to the other two models) the linkage between personal and functional income distribution is formulated as part of a complete macroeconomic system. However, our SFC model moves beyond Palley's work in various important ways: it contains more household groups and more income sources; personal income distribution is captured by inequality indices; the links between functional and personal income distribution are explored using inequality decomposition techniques; there is an explicit formulation of the financial system and the balance sheet structure of households that allows a richer consideration of the interaction between income and wealth. Moreover, contrary to all aforementioned models, the model of this paper is dynamic in nature: it explicitly tracks the stocks and flows of the macroeconomy in a sequential manner. 


\section{The model}

The postulated economy consists of households, firms, an unemployment fund and commercial banks. The household sector is divided into five groups:

(1) Households headed by a low-skilled employed worker. Their income comes from the wage received by their head. They do not save.

(2) Households headed by a low-skilled unemployed. They receive the unemployment benefit. Their head is available to work in a low-skilled job. They do not save.

(3) Households headed by a high-skilled employed worker. Their income comes from the wage received by their head (which is higher than the wage of a low-skilled worker) and the interest paid on their accumulated deposits.

(4) Households headed by a high-skilled unemployed. They receive the unemployment benefit and the interest on their accumulated deposits. Their head is available to work in a high-skilled job. $^{2}$

(5) Households headed by entrepreneurs-capital owners. They are the owners of the enterprises and have accumulated a large amount of wealth (equities and deposits). They receive only capital income in the form of interest and distributed profits.

Households move between groups (1) and (2), according to the demand for low-skilled jobs. Movements also occur between groups (3) and (4) when there are alterations in the demand for high-skilled jobs. It is assumed that low-skilled agents cannot become high-skilled ones by investing in human capital. Furthermore, to avoid unnecessary complications, it is postulated that high-skilled agents do not work in low-skilled jobs. Consequently, the proportion of the sum of households (1) and (2) and of the sum of households (3) and (4) in total household population is exogenously given. Future extensions of the model could allow these 
proportions to change endogenously as a result of low-skilled workers' investment in human capital and variations in the demand for low-skilled and high-skilled labour. The consideration of intergenerational mobility could also be an important extension of the current simplified formulation.

All households are assumed to have the same size and composition. The head of the household is the only income provider. Hence, personal income distribution coincides with household income distribution. Furthermore, it has been posited that the households that belong to the same group have identical income (and wealth). This allows us to focus on between group inequality, avoiding the complications that stem from within group inequality as a result of differences in microeconomic characteristics (such as age, health and personal skills).

Firms run investment projects using both internal funds (retained profits) and external finance (equities and loans). A part of their profits is distributed to the households of entrepreneurscapital owners. Commercial banks provide loans to firms and deposits constitute their only liability. Their profits are all distributed to the households of entrepreneurs-capital owners, who are assumed to be the owners of banks (for simplicity, bank equity is assumed away). The unemployment fund, which is financed by the employees' and employers' contribution, provides unemployment benefits.

Since the aim of this paper is to set up a benchmark model for the analysis of the effects of functional on personal income distribution, a number of simplifying assumptions for the structure of the macroeconomy have been adopted: there are no government expenditures and taxes; unemployment benefits are the only social transfers; income from self-employment is 
not explicitly considered; there is no housing market and thus no income from rent; households do not take out loans from commercial banks. The banking sector has been kept simple: there are no central bank interventions and commercial banks are portrayed as passive intermediaries that provide all loans demanded by firms. Inflation has been assumed away and the price level of output has been set equal to unity (i.e. variables' nominal and real values coincide). Future extensions of the model can relax these assumptions, investigating how the results of our benchmark analysis can be modified when various complications of the reality are taken into account. ${ }^{3}$

Table 1 shows the balance sheets of the economy's sectors. Symbols with a plus sign represent assets and symbols with a negative sign indicate liabilities. Table 2 depicts the transactions between the sectors. In the case of firms and commercial banks, a distinction is made between current and capital transactions. Symbols with a plus sign denote inflows. Symbols with a negative sign depict outflows. The columns of the matrix represent the budget constraints of the sectors.

$<$ Insert Table 1 here $>$

$<$ Insert Table 2 here $>$

We proceed to describe the equations of the model. The subscript "- 1 " is used to denote the values of the endogenous variables in the previous period.

\subsection{Households of low-skilled employed workers}

$Y_{L E}=w_{L} \cdot\left(1-\tau_{W}\right) \cdot N_{L E}$ 
$C_{L E}=Y_{L E}$

$Y H_{L E}=Y_{L E} / N_{L E}$

The disposable income of low-skilled employed workers $\left(Y_{L E}\right)$ equals their wage bill minus their contributions to the unemployment fund (equation 1); $w_{L}$ is their wage rate, $N_{L E}$ is the number of low-skilled employed workers and $\tau_{W}$ is the part of the wage rate paid to the unemployment fund as employee contribution. Equation (2) shows the consumption expenditures of low-skilled employed workers' households $\left(C_{L E}\right)$. The income per household $\left(Y H_{L E}\right)$ is defined in equation (3).

3.2 Households of low-skilled unemployed workers

$$
\begin{aligned}
& N_{L U}=N_{L}-N_{L E} \\
& u r_{L}=1-\left(N_{L E} / N_{L}\right) \\
& u b=\xi \cdot w_{L} \\
& Y_{L U}=u b \cdot N_{L U} \\
& C_{L U}=Y_{L U} \\
& Y H_{L U}=Y_{L U} / N_{L U}
\end{aligned}
$$

The number of households of low-skilled unemployed workers $\left(N_{L U}\right)$ is given by equation (4); $N_{L}$ is the total number of households headed by a low-skilled worker (employed or unemployed). The rate of unemployment for low-skilled workers $\left(u r_{L}\right)$ is defined in equation (5). The unemployment benefit rate $(u b)$ is a proportion $(\xi)$ of the wage rate of low-skilled 
workers (equation 6). Equation (7) gives the disposable income of the low-skilled unemployed workers' households $\left(Y_{L U}\right)$. Equation (8) shows their consumption $\left(C_{L U}\right)$. The income per household ( $\left.Y H_{L U}\right)$ is defined in equation (9).

\subsection{Households of high-skilled employed workers}

$$
\begin{aligned}
& Y_{H E}=w_{H} \cdot\left(1-\tau_{W}\right) \cdot N_{H E}+r_{M} \cdot M_{H E-1} \\
& C_{H E}=N_{H E} \cdot\left[c_{H E 1} \cdot Y H_{H E-1}+c_{H E 2} \cdot\left(M_{H E-1} / N_{H E-1}\right)\right] \\
& \Delta M_{H E}=Y_{H E}-C_{H E}+M T \\
& M T=z_{1} \cdot\left(N_{H U-1}-N_{H U}\right) \cdot\left(M_{H E-1} / N_{H E-1}\right)+z_{2} \cdot\left(N_{H U-1}-N_{H U}\right) \cdot\left(M_{H U-1} / N_{H U-1}\right) \\
& z_{1}=1 \text { iff } N_{H U}>N_{H U-1} ; \text { otherwise } z_{1}=0 \\
& z_{2}=1 \text { iff } N_{H U}<N_{H U-1} ; \text { otherwise } z_{2}=0 \\
& Y H_{H E}=Y_{H E} / N_{H E}
\end{aligned}
$$

Equation (10) gives the disposable income of high-skilled employed workers' households $\left(Y_{H E}\right) ; w_{H}$ is their wage rate, $N_{H E}$ is the number of high-skilled employed workers, $r_{M}$ is the interest rate on deposits and $M_{H E-1}$ stands for their lagged accumulated deposits. The consumption expenditures $\left(C_{H E}\right)$ are defined in equation (11). Following Godley and Lavoie (2007), a Modigliani-type consumption function has been adopted. Thus, the consumption of each household relies on the expected disposable income of the household $\left(\mathrm{YH}_{\mathrm{HE}-1}\right)$ and the past accumulated wealth; $c_{H E 1}$ is the propensity to consume out of income and $c_{H E 2}$ is the propensity to consume out of wealth $\left(0<c_{H E 2}<c_{H E 1}<1\right)$. Total consumption is derived by multiplying the consumption of each household (the term in the bracket) by the number of 
households. Note that all households in the model are assumed to exhibit a simple form of adaptive expectations according to which their expected income and wealth are given by the per household lagged income and wealth in their group.

Equation (12) reflects households' budget constraint. When the households of high-skilled workers change group, as a result of alterations in the unemployment rate, they bring with them their accumulated wealth. At the aggregate level, this wealth needs to be added to the total wealth of their new group and to be subtracted from the total wealth of their previous group. This is ensured by incorporating the term $M T$ in the budget constraint. This term denotes the amount of deposits that is added to the group of high-skilled employed workers. Equations (13), (14) and (15) show that this term is positive when unemployment decreases (i.e. $N_{H U}<N_{H U-1}$ ) and negative when unemployment rises (i.e. $N_{H U}>N_{H U-1}$ ); $N_{H U}$ denotes the number of unemployed high-skilled workers and $M_{H U-1}$ is their lagged accumulated deposits. ${ }^{4}$ The income per household of high-skilled employed workers is defined in equation (16).

3.4 Households of high-skilled unemployed workers

$$
\begin{aligned}
& N_{H U}=N_{H}-N_{H E} \\
& u r_{H}=1-\left(N_{H E} / N_{H}\right) \\
& Y_{H U}=u b \cdot N_{H U}+r_{M} \cdot M_{H U-1} \\
& C_{H U}=N_{H U} \cdot\left[c_{H U 1} \cdot Y H_{H U-1}+c_{H U 2} \cdot\left(M_{H U-1} / N_{H U-1}\right)\right] \\
& \Delta M_{H U}=Y_{H U}-C_{H U}-M T \\
& Y H_{H U}=Y_{H U} / N_{H U}
\end{aligned}
$$


The number of households headed by a high-skilled unemployed worker is given by equation (17); $N_{H}$ is the total number of high-skilled workers' households (employed or unemployed). Equation (18) defines the unemployment rate for high-skilled workers $\left(u r_{H}\right)$ and equation (19) describes the disposable income of the unemployed ones $\left(Y_{H U}\right)$. Equation (20) is the Modigliani-type consumption function where $C_{H U}$ is the total consumption of high-skilled unemployed workers, $\mathrm{YH}_{\mathrm{HU}-1}$ is the lagged disposable income per household, $\mathrm{C}_{\mathrm{HU1}}$ is the propensity to consume out of income and $c_{\mathrm{HU} 2}$ is the propensity to consume out of wealth. Note that, since the income of unemployed high-skilled workers is lower than that of employed ones, it is reasonable to postulate that $c_{\mathrm{HU} 1}>c_{\mathrm{HE1}}$ and $c_{\mathrm{HU} 2}>c_{\mathrm{HE2}}$. Equation (21) shows the budget constraint for the households of high-skilled unemployed workers. Equation (22) defines the income per household.

\subsection{Households of entrepreneurs-capital owners}

$$
\begin{aligned}
& Y_{E}=D P+B P+r_{M} \cdot M_{E-1} \\
& C_{E}=c_{E 1} \cdot Y_{E-1}+C_{E 2} \cdot V_{E-1} \\
& \Delta V_{E}=Y_{E}-C_{E}+C G \\
& C G=\Delta p_{e} \cdot e_{-1} \\
& r e=\frac{D P+C G}{p_{e-1} \cdot e_{-1}} \\
& E=\left[\lambda_{0}+\lambda_{1} \cdot r e_{-1}-\lambda_{2} \cdot r_{M}-\lambda_{3} \cdot\left(Y_{E-1} / V_{E-1}\right)\right] \cdot V_{E-1} \\
& M_{E}=\left[\left(1-\lambda_{0}\right)-\lambda_{1} \cdot r e_{-1}+\lambda_{2} \cdot r_{M}+\lambda_{3} \cdot\left(Y_{E-1} / V_{E-1}\right)\right] \cdot V_{E-1} \\
& M_{E}=V_{E}-E
\end{aligned}
$$


$Y H_{E}=Y_{E} / N_{E}$

The disposable income of entrepreneurs-capital owners' households $\left(Y_{E}\right)$ consists of firms' distributed profits $(D P)$, banks' profits $(B P)$ and the interest on their accumulated deposits $\left(M_{E-1}\right)$ (equation 23). In the Modigliani-type consumption function, described in equation (24), $C_{E}$ denotes the consumption expenditures, $V_{E}$ is the wealth of entrepreneurs-capital owners' households $\left(V_{E}=M_{E}+p_{e} \cdot e\right), c_{E 1}$ is the propensity to consume out of income and $c_{E 2}$ is the propensity to consume out of wealth; it is postulated that $c_{E 1}<c_{H E 1}$ and $c_{E 2}<c_{H E 2}$. The budget constraint is given by identity (25). The capital gains on equities ( CG ) are defined in equation (26); $e$ is the number of equities and $p_{e}$ denotes their price. The rate of return of equities ( $r e$ ) is the sum of distributed profits and capital gains, divided by the lagged value of equities (equation 27).

The households of entrepreneurs-capital owners hold their wealth in the form of equities $(E)$ and deposits. Their portfolio choice, captured by equations (28) and (29n), relies on Godley’s (1999) formulation of imperfect asset substitutability. This formulation suggests that the share of households' wealth held in the form equities and deposits has an exogenous and an endogenous component. The exogenous component, which is represented by parameters $\lambda_{0}$ and $1-\lambda_{0}$, reflects exogenous factors that influence households' asset choice (e.g. the perceived degree of uncertainty). The endogenous component captures the response of asset allocation to alterations in the relative rates on return and the transactions demand for money. According to the balance sheet matrix, equation (29) must always hold. Therefore, equation (29n) is replaced by equation (29) in the computer simulations. Recall that due to the simplifying assumption of adaptive expectations, households' expected wealth is proxied by 
its lagged value. Equation (30) defines the income per household ( $\left.Y H_{E}\right) ; N_{E}$ is the number of households headed by entrepreneurs-capital owners.

\subsection{Firms}

$Y=C+I$

$C=C_{L E}+C_{L U}+C_{H E}+C_{H U}+C_{E}$

$W=w_{L} \cdot N_{L E}+w_{H} \cdot N_{H E}$

$T P=Y-\left(1+\tau_{F}\right) \cdot W-r_{L} \cdot L_{-1}$

$R P=s_{f} \cdot T P$

$D P=T P-R P$

$N_{L E}=Y / \lambda_{L}$

$N_{H E}=Y^{*} / \lambda_{H}$

$\lambda_{L}=\lambda_{L-1} \cdot\left(1+g_{\lambda}\right)$

$\lambda_{H}=\lambda_{H-1} \cdot\left(1+g_{\lambda}\right)$

$Y^{*}=v \cdot K$

$u=Y / Y^{*}$

$w_{L}=s_{W} \cdot \lambda_{L}$

$s_{W}=w_{0}-w_{1} \cdot u r_{L-1}$

$w_{H}=(1-\rho) \cdot m_{W} \cdot w_{L}+\rho \cdot h \cdot\left[\left(Y-w_{L} \cdot N_{L E}-(1-\rho) \cdot m_{W} \cdot w_{L} \cdot N_{H E}-r_{L} \cdot L_{-1}\right) / N_{H E}\right]$

$I=\left[d_{0}+d_{1} \cdot\left(R P_{-1} / K_{-1}\right)+d_{2} \cdot u_{-1}\right] \cdot K_{-1}$

$\Delta K=I$

$\Delta e=x \cdot\left(I / p_{e}\right)$ 
$\Delta L=I-R P-\Delta e \cdot p_{e}$

$p_{e}=E / e$

According to equation (31), output produced by firms $(Y)$ equals total consumption $(C)$ plus investment (I). Total consumption is given by equation (32). Equation (33) defines the wage bill $(W)$ and equation (34) shows the total profits of firms (TP); $\tau_{F}$ is the rate of employer contributions and $r_{L}$ is the interest rate on loans $(L)$. A proportion $\left(s_{f}\right)$ of firms' total profits is retained for investment purposes (equation 35); retained profits are denoted by $R P$. The remaining amount of profits (DP) is distributed to the households of entrepreneurs-capital owners (equation 36).

Following Lavoie (2009), the demand for low-skilled workers is postulated to depend on output (equation 37), while the demand for high-skilled workers is, according to equation (38), proportional to full-capacity output $\left(Y^{*}\right)$. The symbols $\lambda_{L}$ and $\lambda_{H}$ denote the labour productivity of low-skilled and high-skilled workers, respectively. The productivity in our benchmark setup is posited to grow at an exogenously given rate $\left(g_{\lambda}\right)$; see equations (39) and (40). In future extensions of the model labour productivity can become endogenous following, for instance, Cassetti (2003), Naastepad (2006) and Palley (2015). Equation (41) defines the full-capacity output; $v$ is the technologically given full-capacity output-to-capital ratio; $K$ denotes firms’ capital stock. Equation (42) gives the rate of capacity utilisation $(u)$.

The wage rate of low-skilled workers is determined through a bargaining procedure in which workers negotiate their wage rate with reference to labour productivity (the latter is known when bargaining takes place). Equation (43) shows that the wage rate is a proportion ( $s_{W}$ ) of 
labour productivity. Since the price level is equal to $1, s_{W}$ is the share of low-skilled workers' wages in total income. When workers achieve a wage growth that is higher (lower) than labour productivity growth, their wage share increases (decreases). Equation (44) states that the wage share that low-skilled workers can attain in the bargaining procedure relies on: (i) $w_{0}$, which reflects the exogenous factors associated with the institutional structure of the labour market, and (ii) the rate of unemployment. The negative impact of the rate of unemployment on the wage share of low-skilled workers reflects the 'reserve army affect' (see e.g. Stockhammer 2004).

The wage rate of high-skilled workers is determined through a scheme that incorporates profit sharing: in addition to a base wage rate, high-skilled workers receive a variable remuneration linked to firms' profits. ${ }^{5}$ Thus, the overall wage rate is set as a weighted average of the base wage rate and the profit-linked remuneration (equation 45). ${ }^{6}$ The parameter $\rho$ denotes the relative importance of profit sharing in the determination of high-skilled workers' wage rate $(0<\rho<1)$. The base wage rate of high-skilled workers is $m_{W}$ times the wage rate of lowskilled ones, where $m_{W}>1$ is a kind of skill premium; $s_{P}=\rho \cdot h$ is the proportion of per highskilled worker profits that is allocated to high-skilled workers $\left(0<s_{P}<1\right) .^{7}$ The profits out of which the profit-linked remuneration is estimated are equal to the sales of firms minus the wage bill of low-skilled workers, the wage bill of high-skilled workers (without including their profit-linked remuneration) and the interest payments of firms.

Equation (46) is the investment function; $d_{0}, d_{1}$ and $d_{2}$ are parameters. We have opted for a simple specification which postulates that capital accumulation depends positively on the (lagged) rate of retained profits and the (lagged) rate of capacity utilisation (see e.g. Rowthorn 
1982; Dutt 1984). Equation (47) shows the change in capital stock (capital depreciation has been assumed away). Following Lavoie and Godley (2001-2), it is postulated that firms finance a fraction $(x)$ of their investment expenditures via equity emission. This is described by equation (48). Loans from commercial banks close the gap between the desired investment expenditures and the funding that comes from retained profits and equity emission (equation 49). Equation (50) reflects the stock market equilibrium.

\subsection{Unemployment fund}

$$
\begin{aligned}
& C O=\left(\tau_{W}+\tau_{F}\right) \cdot W \\
& U B=u b \cdot\left(N_{L U}+N_{H U}\right) \\
& \Delta M_{F}=C O-U B+r_{M} \cdot M_{F-1}
\end{aligned}
$$

Equation (51) gives the sum of employee and employer contributions (CO). The total amount of unemployment benefits $(U B)$ is defined in equation (52). The part of the contributions not used for the provision of unemployment benefits is saved in the form of deposits $\left(M_{F}\right)$. Equation (53) reflects the budget constraint of the unemployment fund.

\subsection{Commercial banks}

$$
\begin{aligned}
& B P=r_{L} \cdot L_{-1}-r_{M} \cdot M_{-1} \\
& M=M_{H E}+M_{H U}+M_{E}+M_{F} \\
& r_{L}=s p r+r_{M} \\
& M=L
\end{aligned}
$$


Equation (54) gives commercial banks' profits. Total deposits $(M)$ are defined in equation (55). Equation (56) shows that the interest rate on loans equals the deposit interest rate plus a fixed spread ( spr ). Equation (57r) is the 'redundant' identity of the model. The accounting logic suggests that this identity always holds. Thus, it is not included in the solution of the model. However, in the simulations it is necessary to verify that this identity is indeed realised.

\section{Income inequality: indices and decomposition by income source}

Income inequality is measured by three broadly used indices: the Gini coefficient (GINI), the squared coefficient of variation $\left(C^{2}\right)$ and the Atkinson index with $\varepsilon=2\left(A_{\varepsilon=2}\right) ; \varepsilon$ is the inequality aversion parameter.

GINI is written as:

$G I N I=\frac{1}{2 \cdot N^{2} \cdot \mu} \sum_{j} \sum_{i}\left|Y H_{i}-Y H_{j}\right| \cdot N_{i} \cdot N_{j}$

where $N=N_{L}+N_{H}+N_{E}, i, j=L E, L U, H E, H U, E$ and $\mu$ is the mean household income defined as $\mu=Y_{T} / N ; Y_{T}$ is the total household income $\left(Y_{T}=Y_{L E}+Y_{L U}+Y_{H E}+Y_{H U}+Y_{E}\right)$.

$C^{2}$ is expressed as: 
$C^{2}=\frac{1}{N \cdot \mu^{2}} \sum_{i} N_{i} \cdot\left(Y H_{i}-\mu\right)^{2}$

where $i=L E, L U, H E, H U, E$.

$A_{\varepsilon=2}$ is given by:

$A_{\varepsilon=2}=1-\left[\frac{1}{N} \sum_{i} N_{i} \cdot\left[\frac{Y H_{i}}{\mu}\right]^{-1}\right]^{-1}$

where $i=L E, L U, H E, H U, E$.

All these indices take a minimum value of 0 when there is perfect equality. For GINI and $A_{\varepsilon=2}$ the maximum value is 1 (perfect inequality). There is no upper bound for $C^{2}$. The indices differ in their sensitivity to inequalities in different parts of the distribution: GINI is more sensitive to inequalities at the middle of the distribution, $C^{2}$ is more sensitive to inequalities at the top of the distribution and $A_{\varepsilon=2}$ is more sensitive to inequalities at the bottom of the distribution. Therefore, each index captures different aspects of inequality.

In our model, households have the following income sources $(k)$ :

1) labour $(k=1)$ : $\left(1-\tau_{W}\right) \cdot\left(w_{L} \cdot N_{L E}+w_{H} \cdot N_{H E}\right)$

2) unemployment benefits $(k=2): u b \cdot\left(N_{L U}+N_{H U}\right)$

3) profits $(k=3): D P+B P$

4) interest $(k=4): r_{M} \cdot\left(M_{H E-1}+M_{H U-1}+M_{E-1}\right)$ 
To capture and evaluate the impact of each income source on inequality, we decompose inequality by income source. The decomposition enables us to define total inequality as the sum of the contributions of each source:

$I=\sum S_{k}$

where $I$ is the total inequality and $S_{k}$ is the absolute contribution of the income source $k$ to total inequality ( $k=1,2,3,4$ ). The relative contribution of the income source $k$ to total inequality $\left(s_{k}\right)$ is written as:

$S_{k}=\frac{S_{k}}{I}$

Suitable values of $s_{k}$ are derived using decomposition rules. Employing Shorrock’s (1982, 1983) suggested decomposition rule, the relative contribution of the income source $k$ to total inequality is estimated as:

$s_{k}=\frac{\operatorname{cov}\left(y_{k}, y\right)}{\sigma^{2}}=\frac{\rho_{k} \cdot \sigma_{k}}{\sigma}$

where $\operatorname{cov}\left(y_{k}, y\right)$ is the covariance between the income of each household from source $k\left(y_{k}\right)$ and the total disposable income of each household $(y), \sigma^{2}$ and $\sigma$ denote, respectively, the variance and the standard deviation of the total disposable income of households, $\sigma_{k}$ is the 
standard deviation of income source $k$ and $\rho_{k}$ is the correlation between the income of each household from source $k$ and the total disposable income of the household.

Following the common practice in the related literature (e.g. Jenkins 1995; Jännti 1997; Papatheodorou 1998; Fräßdorf, Grabka and Schwarze 2011; García-Peñalosa and Orgiazzi 2013), the decomposition is performed using the squared coefficient of variation as inequality index. Therefore, the absolute contribution of income source $k$ to total inequality $\left(S_{k}^{C}\right)$ is estimated as:

$$
S_{k}^{C}=s_{k} \cdot C^{2}=\frac{\rho_{k} \cdot \sigma_{k} \cdot \sigma}{\mu^{2}}=f s_{k} \cdot \rho_{k} \cdot \sqrt{C_{k}^{2} \cdot C^{2}}
$$

where $f s_{k}$ is the factor share given by the ratio $\mu_{k} / \mu$ ( $\mu_{k}$ is the mean income from source $k$ ) and $C_{k}^{2}$ is the squared coefficient of variation of source $k$. Note that $C^{2}=\sigma^{2} / \mu^{2}$ and $C_{k}^{2}=\sigma_{k}^{2} / \mu_{k}^{2}$.

\section{Simulation exercises}

The model presented in Section 3 has been solved using numerical simulations. ${ }^{8}$ In the simulations the model is allowed to operate sequentially until a steady state is reached. The values for the parameters and the exogenous variables are reported in Appendix A. ${ }^{9}$ These values (as well as the initial values for the endogenous variables) have been selected so as to obtain a steady state with plausible values for the endogenous variables. The steady-state values of the key endogenous variables are reported in Appendix B. ${ }^{10}$ 
At $t=0$ we impose two shocks that reflect exogenous changes in the functional distribution of income: (1) a rise in $w_{0}$, which may stem from institutional changes in the labour market that push up the wage share of low-skilled workers; (2) an increase in the dividend payout ratio of firms $\left(1-s_{f}\right)$, which in the related literature is associated with financialisation (see, e.g., van Treeck 2009 and Hein and van Treeck, 2010). The simulations illustrate how these exogenous changes in functional income distribution influence personal income distribution in the short run and the long run. They also show the feedback effects of personal income distribution on functional income distribution.

The interaction between functional and personal income distribution relies to a significant extent on the macroeconomic effects of the alterations in functional income distribution. These effects depend crucially on the sensitivity of the investment rate to the rate of retained profits and the utilisation rate (see equation 46). When the sensitivity to the utilisation rate is relatively high and the sensitivity to the profit rate is relatively low, investment is more likely to increase as a result of a rise in the wage share of low-skilled workers: the favourable effects on consumption (and, thus, on utilisation rate) are more likely to outweigh the adverse effects on the profit rate. Moreover, in this case there is a higher likelihood that investment will increase as a result of an increase in the dividend payout ratio, which places upward pressures on consumption and downward pressures on the rate of retained profits. On the other hand, when the sensitivity of the investment rate to the profit rate is relatively high and the sensitivity of the utilisation rate is relatively low, investment is more likely to decline when the wage share of low-skilled workers and the dividend payout ratio increase. 
Therefore, in our simulations a distinction is made between two cases:

- Case I: The sensitivity of the investment rate to the rate of retained profits is relatively low and the sensitivity of the investment rate to the utilisation rate is relatively high $\left(d_{1}=0.5\right.$ and $\left.d_{2}=0.03\right)$.

- Case II: The sensitivity of the investment rate to the rate of retained profits is relatively high and the sensitivity of the investment rate to the utilisation rate is relatively low $\left(d_{1}=1.5\right.$ and $\left.d_{2}=0.01\right)$.

The parameters values in Case I are more conducive to a wage-led investment and demand regime than the parameter values in Case II, which are more conducive to a profit-led investment and demand regime (for a description of these regimes see Lavoie and Stockhammer, 2013). ${ }^{11}$

The simulation results are presented in Figures 1-4. With the exception of the factor shares and the absolute contribution to inequality, all the other variables are expressed as a ratio of their steady-state values in the baseline solution. For the definition of the variables that are presented in these figures and are not captured by the equations described in Sections 3 and 4, see Appendix B.

\subsection{Effects of the wage shock}

Figure 1 shows the impact of a rise in the exogenous component of low-skilled workers' wage share under Case I. As expected, immediately after the shock, the share of labour income in total household income increases (Figure 1a). This is the main reason behind the initial 
reduction of the absolute contribution of profits to total inequality (Figure 1b). The shock is beneficial to the wage rate of low-skilled workers but has conflicting effects on the wage rate of high-skilled workers: on the one hand, their base wage rate increases but, on the other hand, their remuneration linked with the profits of firms is adversely affected. Moreover, the shock has clearly negative effects on the income of entrepreneurs-capital owners since the distributed profits of firms are driven down. As a consequence, in the first periods after the shock the income of entrepreneurs-capital owners decreases relative to the income of highskilled and low-skilled workers; furthermore, the ratio of the income of high-skilled to lowskilled workers declines (Figure 1c).

$<$ Insert Figure 1 here $>$

These developments place downward pressures on total inequality. As shown in Figure 1d, inequality falls according to all indices. Remarkably, in the first periods after the shock the drop in inequality is higher according to $C^{2}$ (which is more sensitive to changes in entrepreneurs-capital owners' income) and $A_{(\varepsilon=2)}$ (which is particularly sensitive to changes in low-skilled workers' incomes). This happens because the income of entrepreneurs-capital owners and low-skilled workers are mostly affected by the shock.

Figures 1e-1h show the macroeconomic effects of the shock. The wage share of low-skilled workers increases; there is also initially a slight increase in the wage share of high-skilled workers (Figure 1e). This redistribution of income towards households with a higher propensity to consume reduces the aggregate saving ratio (Figure 1e) and boosts consumption (Figure 1f). In Case I the sensitivity of the investment rate to the rate of retained profits is 
relatively low while the sensitivity to the utilisation rate is relatively high. Consequently, the investment rate increases since the rise in the utilisation rate (triggered by the higher consumption rate) overcompensates the decline in the rate of retained profits (which is shown in Figure 1h). The rise in consumption and investment trigger an increase in the growth rate of output and a decline in the unemployment rate (Figure 1g). Overall, in the first periods, the wage shock reduces inequality and increases macroeconomic activity.

However, there are some important medium-run and long-run effects. Since investment increases despite the reduction in the rate of retained profits, the indebtedness of firms is adversely affected: the loans-to-output ratio starts increasing some periods after the shock (Figure 1h). Since loans are equal to deposits in the model (see equation 57r), the deposits-tooutput ratio also increases.

The rise in $L / Y$ and $D / Y$ affects the income share of both entrepreneurs-capital owners and high-skilled workers. In particular, the income share of entrepreneurs-capital owners is positively affected primarily because the output share of bank profits and entrepreneurscapital owners' interest payments tend to increase; it is negatively affected because the rise in $L / Y$ tends to reduce the profits of firms. In our model the positive effects overcompensate the negative ones basically because the entrepreneurs-capital owners receive only a part of firms' profits while they receive all bank profits.

The income share of high-skilled workers is negatively affected since the rise in $L / Y$ tends to reduce their remuneration linked with the profits of firms; it is positively affected due to the rise in the output share of their interest payments. Since in our simulations, the deposit 
interest rate is relatively low, the negative effects dominate and, hence, the rise in $L / Y$ reduces the income share of high-skilled workers.

The income share of high-skilled workers is also negatively affected by the rise in the rate of capacity utilisation. Using equations (38) and (42), it can be easily shown that the wage share of high-skilled employed workers (given by the ratio $\left[\left(w_{H} \cdot N_{H E}\right) / Y\right]$ ) is inversely linked with the rate of capacity utilisation. Intuitively, this happens because the demand for high-skilled workers depends on $Y^{*}$ and not on $Y$. Hence, for $w_{H}, \lambda_{H}$ and $Y^{*}$ given, an increase in output (and thus in utilisation rate) leaves the wage bill of high-skilled workers unchanged.

As a result of the aforementioned developments, the wage share of high-skilled workers declines after the initial slight increase (Figure 1e); moreover, after the initial fall, the income of entrepreneurs-capital owners gradually increases relative to the income of workers (Figure 1c). Therefore, there is an increase in the absolute contribution of profits to inequality (Figure 1b) and, thus, a rise in inequality (Figure 1d). Remarkably, the rise in the squared coefficient of variation is much more important than the rise in the other two inequality indices (Figure 1d). The main reason is that $C^{2}$ is more responsive to changes in the upper part of the income distribution. An additional reason is that the decline in the wage share of high-skilled workers places downward pressures on $A_{(\varepsilon=2)}$ and probably on GINI.

The continuous decline in the profit rate of firms, due to an increase in their indebtedness, ultimately brings about a fall in the investment rate. This rate gradually goes back to its baseline level (Figure 1f). The same happens with the growth rate of output (Figure 1g). As a result, in the very long run (after the first 100 periods) the economy converges to a new steady 
state. In the new steady state $C^{2}$ is higher than its initial value, but $A_{(\varepsilon=2)}$ and GINI are below their baseline levels.

Figure 2 shows the effects of the wage shock under Case II. The initial effects on inequality are almost identical to Case I. Nonetheless, there are some noteworthy differences in the macroeconomic outcomes. Since the sensitivity of the investment rate to the rate of retained profits is relatively high and the sensitivity to the utilisation rate is relatively low, the investment rate now becomes lower than in the baseline solution (Figure 2f). Therefore, shortly after the initial increase, the utilisation rate and the growth rate of output drop for some periods, following the decline in investment (see Figures $2 \mathrm{f}$ and $2 \mathrm{~g}$ ); in addition, the unemployment rate of low-skilled workers increases, reducing their bargaining power and, therefore, their wage share (Figure 2e). ${ }^{12}$ As a result, the share of labour in total household income declines after the initial increase (Figure 2a) and there is also a rise in the absolute contribution of profits to total inequality (Figure 2b). This produces an increase in inequality according to all indices (Figure 2d).

$<$ Insert Figure 2 here $>$

Gradually, profitability starts recovering (Figure $2 \mathrm{~h}$ ) due to the positive effects of the wage shock on consumption and, thus, on utilisation rate (Figure 2f). The rise in the rate of retained profits pushes the investment rate upwards with positive feedback effects on utilisation rate and consumption rate. This induces a rise in the growth rate of output and a decline in the unemployment rate of low-skilled workers (Figure 2g). Importantly, the increase in economic activity is accompanied by an only slight increase in the loans-to-output ratio in the long run 
(Figure 2h): compared with Case I, the change in the investment rate is much more in line with the change in profitability. Consequently, although there is a redistribution of income towards the entrepreneurs-capital owners (Figure 2c), which increases inequality (Figure 2d), this redistribution is less important than in Case I. In the very long run all indices remain below their baseline levels.

\subsection{Effects of the dividend payout ratio shock}

We now turn to the effects of an exogenous increase in the dividend payout ratio of firms under Case I. Since this increase produces a rise in the distributed profits of firms, in the first periods after the shock the share of profits in household income increases and the share of labour declines (Figure 3a). As a result of this change in functional income distribution, the absolute contribution of profits to total inequality increases (Figure 3b), the income of entrepreneurs-capital owners becomes higher relative to the income of low-skilled and highskilled workers (Figure 3c) and personal income distribution becomes more dispersed (Figure 3d). As expected, $C^{2}$ increases more than the other two indices due to its higher sensitivity to income changes at the top of the distribution.

<Insert Figure 3 here $>$

The macroeconomic effects of the shock are similar to those reported in Figure 1. The rise in distributed profits increases the income of entrepreneurs-capital owners, leading to higher consumption (Figure 3f). Owing to the higher consumption, the utilisation rate increases producing a rise in the investment rate, after the initial decline (Figure 3f); this happens because in Case I the sensitivity of the investment rate to the utilisation rate is relatively high 
while the sensitivity to the rate of retained profits is relatively low. Consequently, the growth rate of output increases and the unemployment rate of low-skilled workers falls (Figure 3g). The latter causes an increase in the wage share of low skilled workers (Figure 3e), producing after some periods a passing decline in inequality (Figure 3d).

In the long run, the decoupling of the investment rate from the rate of retained profits causes a rise in the loans-to-output ratio (Figure 3h). Combined with the increase in the utilisation rate, this produces an increase in the income share of entrepreneurs-capital owners (the reasons are similar to those mentioned in Section 5.1). Therefore, over time the redistribution of income towards the entrepreneurs-capital owners produces an additional rise in inequality, which is primarily reflected in $C^{2}$.

In Case II, the initial effects of the dividend payout ratio shock are the same as those observed in Case I: inequality increases according to all indices (Figure 4d). Nonetheless, after the very first periods the decline in economic activity (Figure 4g) and the increase in the loans-tooutput ratio (Figure 4h), generated by the fall in the rate of retained profits, have a detrimental impact on the wage share of low-skilled workers (Figure 4e) and a beneficial impact on the household income share of entrepreneurs-capital owners (Figure 4c). As a result, the initial increase in inequality is reinforced (Figure 4d).

$<$ Insert Figure 4 here $>$

After some periods, the rise in the utilisation rate and the growth rate of output reduces the unemployment rate of low-skilled workers (Figure 4g), increasing their wage share (Figure 4e). Moreover, the loans-to-output ratio falls (Figure 4h), placing downward pressures on the 
household income share of entrepreneurs-capital owners (Figure 4c). Consequently, a small decline in inequality is reported (Figure 4d). In the long run, however, inequality increases again slightly (due to the small rise in the loans-to-output ratio) and all inequality indices stabilise at a new steady state in which their value is higher than the pre-shock level.

\subsection{Additional remarks}

Three additional remarks are in order. First, as Figures 1c, 2c, 3c and 4c indicate, the deposit ratio (i.e. the ratio of per household deposits of entrepreneurs-capital owners to per household deposits of high-skilled workers) follows with a time lag the changes in the respective income ratio. The reason is straightforward: when the income gap between these two household groups decreases (increases) the same happens in the saving gap and therefore in the deposit gap (given that the substitution between deposits and equities on the part of entrepreneurscapital owners is not significant enough). At the same time, any reduction (increase) in the deposit ratio tends to reduce (increase) the interest income of entrepreneurs-capital owners relative to the interest income of high-skilled workers, further reducing the income gap between these types of households and, thereby, the deposit ratio. This implies that the accumulation of wealth can magnify the initial personal income distribution effects of a change in functional income distribution. Notice that it is precisely the use of the stock-flow consistent framework that allows us to capture the dynamic interaction between wealth and income distribution and its implications for the link between functional and personal income distribution.

Second, the medium-run and long-run effects of the shocks, which are associated with macroeconomic developments, indicate why the link between functional and personal income 
distribution is necessary to be explored within the structure of a complete macroeconomic system. The macroeconomic channels are capable of modifying the initial impacts of functional on personal income distribution. Therefore, the non-consideration of these channels would render the analysis static, partial and, potentially, misleading.

Third, although the starting point in our simulations is a shock that captures changes in functional income distribution, our exercises do not solely consider the effects of functional on personal income distribution: they also encapsulate the feedback effects of personal on functional income distribution. For instance, when a change in functional income distribution leads to lower unemployment, various unemployed workers become employed and personal income distribution tends to become less dispersed. This, in turn, leads to a higher consumption that affects macroeconomic activity and, hence, functional income distribution. Another example is when the initial change in functional income distribution induces a redistribution of interest income from entrepreneurs-capital owners towards high-skilled workers. This change in personal income distribution affects consumption and, therefore, functional income distribution through the various macroeconomic channels.

\section{Conclusions}

The absence of an integrated framework that connects functional with personal income distribution constitutes a major gap in modern economic theory. Using an SFC macro modelling framework, we put forward a benchmark platform that provides the basis for a fresh theoretical look at the links between the two types of income distribution. The distinct feature of the suggested platform is the rigorous modelling of the stock-flow interactions in the economy. This permits the formulation of the links between functional and personal 
income distribution as part of a complete macroeconomic system. It also enables the explicit consideration of the income-wealth interrelationship.

With the aid of simulations, we explored the effects of a wage and a dividend payout ratio shock on personal income distribution. The purpose of the simulation analysis was to reveal the various complex ways through which functional and personal income distribution interact and to highlight the crucial role played by the macroeconomic system. According to the results, an increase in the exogenous component of the wage share of low-skilled workers (for example, due to changes in labour market institutions) reduces inequality in the short run. In the medium to long run, inequality starts increasing, but remains below the initial level in almost all cases. This rise stems from the fall in profitability that either increases the indebtedness of firms (benefiting the top incomes) or reduces investment and employment (driving down the wage share). Therefore, although policies that increase low wages seem generally to produce a decline in inequality, their beneficial effects can be less significant in the long run than in the short run.

An increase in the dividend payout ratio of firms (for example, due to financialisation) benefits, in the short run, the income of entrepreneurs-capital owners leading to higher inequality. In the medium to long run, the initial increase in inequality is (to a larger or lower extent) reinforced either due to the decline in investment and employment or due to the increase in the indebtedness of firms.

The benchmark model developed here opens the avenue for further research. An important line of inquiry involves the introduction of more micro-based behaviours and structures into the model of this paper. The recently developed agent-based modelling (see e.g., Lengnick 
2013) can prove a useful platform in this direction. The consideration of more complex macroeconomic relationships and financial structures is also an obvious direction for future research, as alluded to in Section 3. These extensions can be part of a broad research programme geared towards the establishment of a more thorough understanding of the complex links between functional and personal income distribution. 


\section{References}

Atkinson, A.B. 2009. “Factor shares: The principal problem of political economy?” Oxford Review of Economic Policy 25 (1): 3-16.

Backus, D., W.C. Brainard, G. Smith, and J. Tobin. 1980. “A model of U.S. financial and nonfinancial economic behavior.” Journal of Money, Credit and Banking 12 (2): 259-293.

Carvalho, L., and A. Rezai. 2014. "Personal income inequality and aggregate demand.” Department of Economics, University of São Paulo, Working paper 2014-23.

Cassetti, M. (2003). "Bargaining power, effective demand and technical progress." Cambridge Journal of Economics 27 (3): 449-464.

Checchi, D., and C. García-Peñalosa. 2010. “Labour market institutions and the personal distribution of income in the OECD.” Economica 77 (307): 413-450.

Cripps, F., and W. Godley. 1976. "A formal analysis of the Cambridge Economic Policy Group model.” Economica 43 (172): 335-348.

Dafermos, Y. 2012. "Liquidity preference, uncertainty, and recession in a stock-flow consistent model.” Journal of Post Keynesian Economics 34 (4): 749-776.

Dagum, C. 1999. "Linking functional and personal distributions of income.” In Handbook of Income Inequality, edited by J. Silber, 101-128. Boston/Dordrecht/London: Kluwer Academic Publishers.

Daudey, E., and C. García-Peñalosa. 2007. “The personal and the factor distributions of income in a cross-section of countries.” Journal of Development Studies 43 (5): 812-829.

Dutt, A.K. 1984. "Stagnation, income distribution and monopoly power.” Cambridge Journal of Economics 8 (1): 25-40. 
Fräßdorf, A., M.M. Grabka, and J. Schwarze. 2011. “The impact of household capital income on income inequality-a factor decomposition analysis for the UK, Germany and the USA.” Journal of Economic Inequality 9 (1): 35-56.

García-Peñalosa, C., and E. Orgiazzi. 2013. "Factor components of inequality: A crosscountry study.” Review of Income and Wealth 59 (4): 689-727.

Godley, W. 1999. "Money and credit in a Keynesian model of income determination.” Cambridge Journal of Economics 23 (4): 393-411.

Godley, W., and M. Lavoie. 2007. Monetary Economics: An Integrated Approach to Credit, Money, Income, Production and Wealth. Basingstoke: Palgrave Macmillan.

Hein, E. 2014. Distribution and Growth after Keynes: A Post-Keynesian Guide, Cheltenham, UK and Northampton, MA, USA: Edward Elgar.

Hein, E., and T. van Treeck. 2010. "Financialisation and rising shareholder power in Kaleckian/post-Kaleckian models of distribution and growth.” Review of Political Economy 22 (2): 205-233.

Jännti, M. 1997. “Inequality in five countries in the 1980s: The role of demographic markets and government policies.” Economica 64 (255): 415-440.

Jenkins, S.P. 1995. “Accounting for inequality trends: Decomposition analyses for the UK, 1971-86. ” Economica 62 (245): 29-63.

Lavoie, M. 2009. “Cadrisme within a post-Keynesian model of distribution and growth.” Review of Political Economy 21 (3): 369-391.

Lavoie, M., and W. Godley. 2001-2. "Kaleckian models of growth in a coherent stock-flow monetary framework: A Kaldorian view.” Journal of Post Keynesian Economics 24 (2): 277-312.

Lavoie, M., and E. Stockhammer. 2013. "Wage-led growth: Concept, theories and policies.” Conditions of Work and Employment Series No. 41, ILO. 
Le Heron, E., and T. Mouakil. 2008. “A Post-Keynesian stock-flow consistent model for dynamic analysis of monetary policy shock on banking behaviour.” Metroeconomica 59 (3): 405-440.

Lengnick, M. 2013. “Agent-based macroeconomics: A baseline model.” Journal of Economic Behavior and Organization 86: 102-120.

Lima, G.T. 2012. “A neo-Kaleckian model of profit sharing, capacity utilization and economic growth.” Metroeconomica 63 (1): 92-108.

Naastepad, C.W.M. 2006. “Technology, demand and distribution: A cumulative growth model with an application to the Dutch productivity growth slowdown.” Cambridge Journal of Economics 30 (3): 403-434.

OECD 2011. "From household income earnings to disposable household income inequality.” In Divided We Stand: Why Inequality Keeps Rising, 225-258, OECD Publishing.

Palley, T.I. 2015. "The middle class in macroeconomics and growth theory: A three-class neo-Kaleckian-Goodwin model.” Cambridge Journal of Economics 39 (1): 221-243.

Papatheodorou, C. 1998. “Inequality in Greece: An analysis by income source.” Discussion Paper DARP No. 39, STICERD, LSE.

Piketty, T. 2014. Capital in the $21^{\text {st }}$ Century, Cambridge, Massachusetts and London, England: The Belknap Press of Harvard University Press.

Rowthorn, B. 1982. "Demand, real wages and economics growth.” Studi Economici, 18: 3-53.

Ryoo, S. and P. Skott. 2008. "Financialization in Kaleckian economies with and without labor constraints.” European Journal of Economics and Economic Policies: Intervention 5 (2): 357-386.

Schlenker, E. and K.D. Schmid. 2013. "Capital income shares and income inequality in the European Union.” IMK working paper 119, Macroeconomic Policy Institute at the HansBoeckler Foundation. 
Shorrocks, A.F. 1982. "Inequality decomposition by factor components.” Econometrica 50 (1): 193-212.

Shorrocks, A.F. 1983. "The impact of income components on the distribution of family incomes.” Quarterly Journal of Economics 98 (2): 311-326.

Stockhammer, E. 2004. "Is there an equilibrium rate of unemployment?” Review of Political Economy 16 (1): 59-77.

Tobin, J. 1982. "Money and finance in the macroeconomic process." Journal of Money, Credit and Banking 14 (2): 171-204.

van Treeck, T. 2009. “A synthetic, stock-flow consistent macroeconomic model of ‘financialisation'.” Cambridge Journal of Economics 33 (3): 467-493.

Weitzman, M.L. 1985. “The simple macroeconomics of profit sharing.” American Economic Review 75(5): 937-953.

Wolff, E.N. and A. Zacharias. 2013. "Class structure and economic inequality.” Cambridge Journal of Economics 37 (6): 1381-1406

Zezza, G. 2008. "US growth, the housing market, and the distribution of income.” Journal of Post Keynesian Economics 30 (3): 375-401. 


\section{Footnotes}

1. These effects of functional income distribution on macroeconomic activity have been extensively investigated in modern post-Keynesian approaches that draw on the analyses of Kaldor, Kalecki, Pasinetti, Robinson and Steindl (see Hein 2014 for a recent review).

2. Instead of categorising workers between low-skilled and high-skilled ones, another option would be to adopt the distinction between workers (or non-supervisory labour) and managers (or supervisory labour) (see, e.g., Lavoie 2009; Palley 2015). This, however, would not change the essence of the arguments developed in the paper.

3. These extensions can draw on the works of Godley and Lavoie (2007), Le Heron and Mouakil (2008), Zezza (2008), van Treeck (2009) and Dafermos (2012).

4. Due to the simplifying assumption that all households that belong to the same group have the same deposits (which are equal to the average deposits of the group), the formulation of deposit transfers suffers from a minor drawback when some unemployed become employed and then some employed become unemployed. In this case, those that become unemployed bring with them an amount of deposits that is lower than the amount actually accumulated, because the average deposits of the employed have been previously reduced due to the inflow of unemployed into employed. A similar issue exists when some employed become unemployed and then some unemployed become employed. However, it should be pointed out that these issues are of minor importance since they can only marginally affect the results of our analysis.

5. For simplicity, we do not consider the potential beneficial effects of profit sharing on labour productivity. See Lima (2012) for a discussion and a formulation of these effects.

6. See Weitzman (1985) and Lima (2012) for similar specifications. 
7. Note that $h=g(\rho)$ and $g^{\prime}(\rho)<0$. Since $h$ is a function of $\rho$, we have that $s_{P}=f(\rho)$. It is also posited that $f^{\prime}(\rho)>0$.

8. The EViews code is available upon request.

9. In the simulations the population is constant. Low-skilled workers, high-skilled workers and entrepreneurs-capital owners represent $55 \%, 40 \%$ and $5 \%$ of the total number of households, respectively. A slightly different composition would imply different steady-state values for the inequality indices but would not change the core results of the simulation exercises.

10. The steady-state values of the inequality indices are low (relative to those observed in reality) primarily because our model captures only inter-group inequality and not intra-group inequality. An additional reason is that the total wage share is relatively high.

11. Given the importance of the investment function for the macro channels through which functional and personal income distribution interact, future extensions of the model could make use of more complicated investment functions and consider more cases based on the responsiveness of investment to various factors (such as the Tobin's q, the leverage ratio and the employment rate). The analyses in Ryoo and Skott (2008) and van Treeck (2009) could be a starting point for these extensions.

12. The unemployment rate of high-skilled workers increases due to the adverse impact of lower investment activity on capital stock. 
Tables and Figures

Table 1: Balance sheet matrix

\begin{tabular}{|c|c|c|c|c|c|c|c|c|c|}
\hline & \multicolumn{5}{|c|}{ Households of } & \multirow[t]{2}{*}{ Firms } & \multirow{2}{*}{$\begin{array}{l}\text { Unemployment } \\
\text { fund }\end{array}$} & \multirow{2}{*}{$\begin{array}{c}\text { Commercial } \\
\text { banks }\end{array}$} & \multirow[t]{2}{*}{ Tota } \\
\hline & $\begin{array}{c}\text { Low-skilled } \\
\text { employed } \\
\text { workers }\end{array}$ & $\begin{array}{c}\text { Low-skilled } \\
\text { unemployed } \\
\text { workers }\end{array}$ & $\begin{array}{c}\text { High-skilled } \\
\text { employed } \\
\text { workers } \\
\end{array}$ & $\begin{array}{c}\text { High-skilled } \\
\text { unemployed } \\
\text { workers } \\
\end{array}$ & $\begin{array}{l}\text { Entrepreneurs- } \\
\text { capital owners }\end{array}$ & & & & \\
\hline Deposits & & & $+M_{H E}$ & $+M_{H U}$ & $+M_{E}$ & & $+M_{F}$ & $-M$ & 0 \\
\hline Equities & & & & & $+e \cdot p_{e}$ & $-e \cdot p_{e}$ & & & 0 \\
\hline Loans & & & & & & $-L$ & & $+L$ & 0 \\
\hline Capital & & & & & & $+K$ & & & $+K$ \\
\hline Total (net worth) & 0 & 0 & $+M_{H E}$ & $+M_{H U}$ & $+V_{E}$ & $+V_{F}$ & $+M_{F}$ & 0 & $+K$ \\
\hline
\end{tabular}


Table 2: Transactions matrix

\begin{tabular}{|c|c|c|c|c|c|c|c|c|c|c|c|}
\hline & \multicolumn{5}{|c|}{ Households of } & \multicolumn{2}{|c|}{ Firms } & \multirow{2}{*}{$\begin{array}{l}\text { Unemployment } \\
\text { fund }\end{array}$} & \multicolumn{2}{|c|}{ Commercial banks } & \multirow[t]{2}{*}{ Total } \\
\hline & $\begin{array}{c}\text { Low-skilled } \\
\text { employed } \\
\text { workers }\end{array}$ & $\begin{array}{c}\text { Low-skilled } \\
\text { unemployed } \\
\text { workers }\end{array}$ & $\begin{array}{c}\text { High-skilled } \\
\text { employed } \\
\text { workers }\end{array}$ & $\begin{array}{c}\text { High-skilled } \\
\text { unemployed } \\
\text { workers }\end{array}$ & $\begin{array}{l}\text { Entrepreneurs- } \\
\text { capital owners }\end{array}$ & Current & Capital & & Current & Capital & \\
\hline Consumption & $-C_{L E}$ & $-C_{L U}$ & $-C_{H E}$ & $-C_{H U}$ & $-C_{E}$ & $+C$ & & & & & 0 \\
\hline Investment & & & & & & $+I$ & $-I$ & & & & 0 \\
\hline Wages & $+w_{L} \cdot N_{L E}$ & & $+w_{H} \cdot N_{H E}$ & & & $-W$ & & & & & 0 \\
\hline Unemployment benefits & & $+u b \cdot N_{L U}$ & & $+u b \cdot N_{H U}$ & & & & $-U B$ & & & 0 \\
\hline Firms' profits & & & & & $+D P$ & $-T P$ & $+R P$ & & & & 0 \\
\hline Commercial banks' profits & & & & & $+B P$ & & & & $-B P$ & & 0 \\
\hline Contributions & $-\tau_{W} \cdot w_{L} \cdot N_{L E}$ & & $-\tau_{W} \cdot w_{H} \cdot N_{H E}$ & & & $-\tau_{F} \cdot W$ & & $+\mathrm{CO}$ & & & 0 \\
\hline Deposit transfers & & & $+M T$ & $-M T$ & & & & & & & 0 \\
\hline Interest on deposits & & & $+r_{M} \cdot M_{H E-1}$ & $+r_{M} \cdot M_{H U-1}$ & $+r_{M} \cdot M_{E-1}$ & & & $+r_{M} \cdot M_{F-1}$ & $-r_{M} \cdot M_{-1}$ & & 0 \\
\hline Interest on loans & & & & & & $-r_{L} \cdot L_{-1}$ & & & $+r_{L} \cdot L_{-1}$ & & 0 \\
\hline$\Delta$ deposits & & & $-\Delta M_{H E}$ & $-\Delta M_{H U}$ & $-\Delta M_{E}$ & & & $-\Delta M_{F}$ & & $+\Delta M$ & 0 \\
\hline$\Delta$ equities & & & & & $-\Delta e \cdot p_{e}$ & & $+\Delta e \cdot p_{e}$ & & & & 0 \\
\hline$\Delta$ loans & & & & & & & $+\Delta L$ & & & $-\Delta L$ & 0 \\
\hline Total & 0 & 0 & 0 & 0 & 0 & 0 & 0 & 0 & 0 & 0 & 0 \\
\hline
\end{tabular}


Figure 1. Effects of an increase in the exogenous component of the low-skilled workers' wage share, Case I

(a) Factor shares

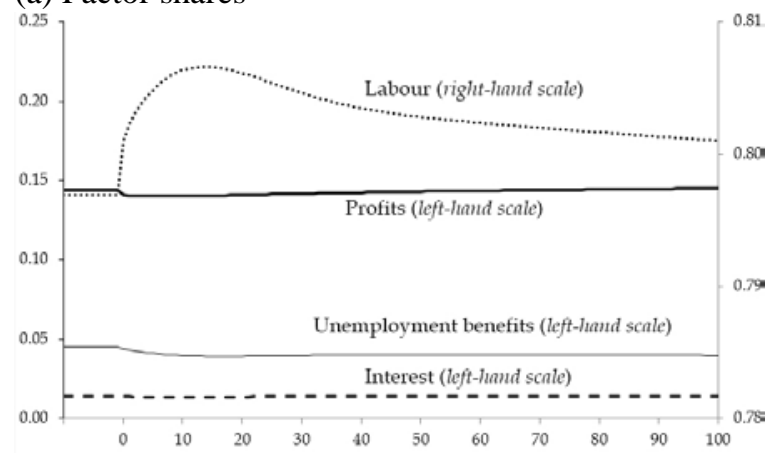

(c) Income ratios and deposit ratio

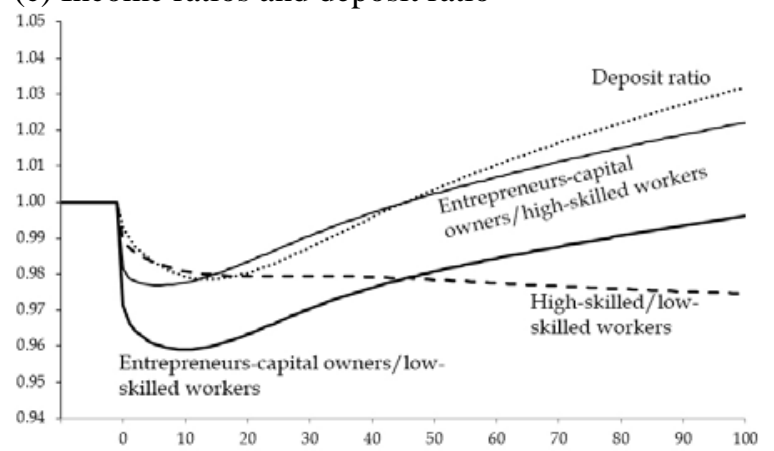

(e) Wage share and aggregate saving ratio

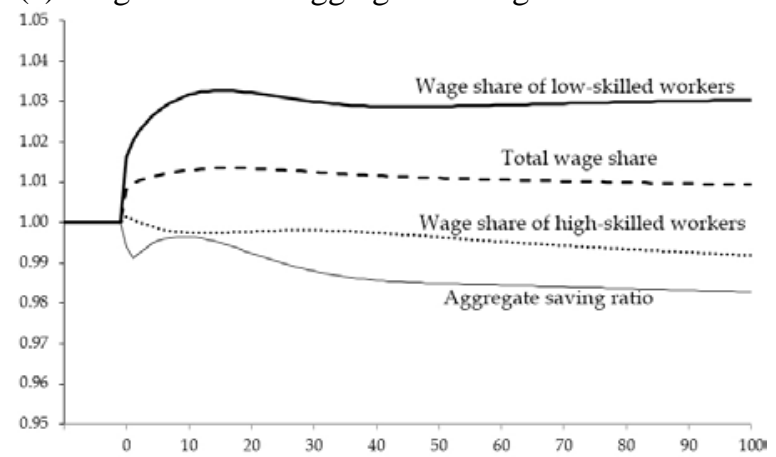

(g) Unemployment rates and growth rate of output

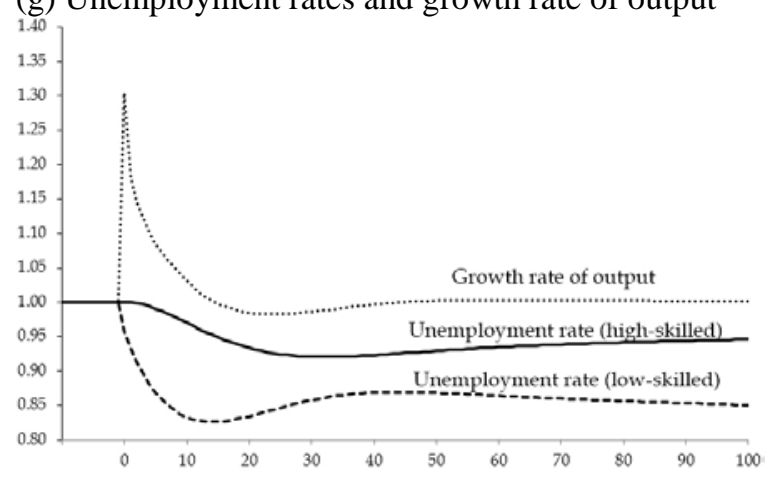

(b) Absolute contribution to inequality

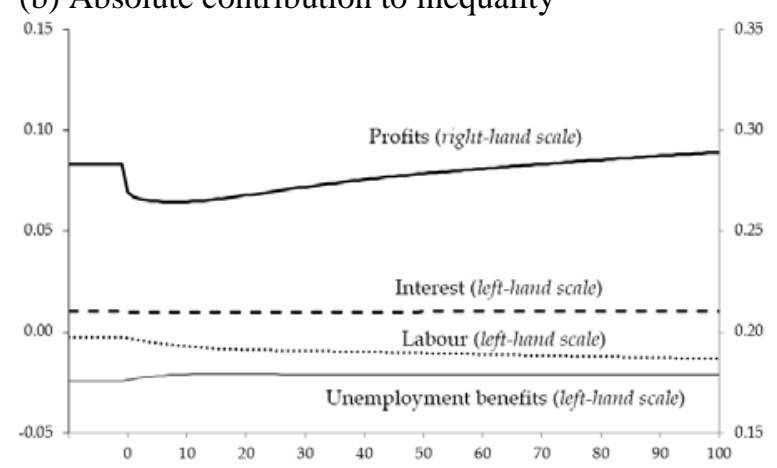

(d) Inequality indices

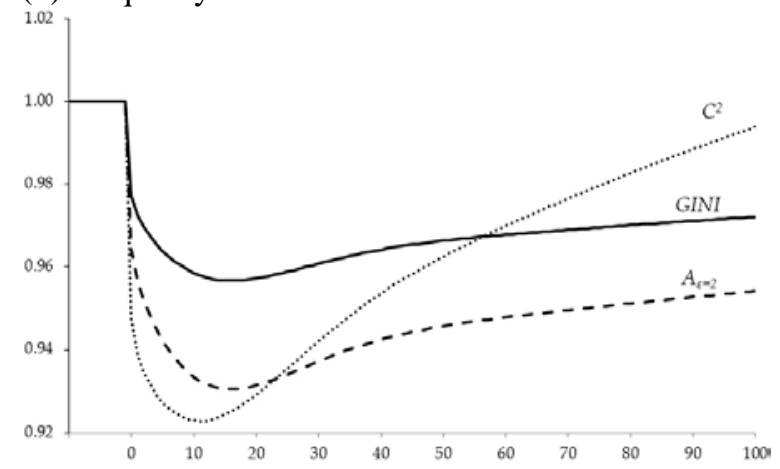

(f) Utilisation, consumption and investment rate

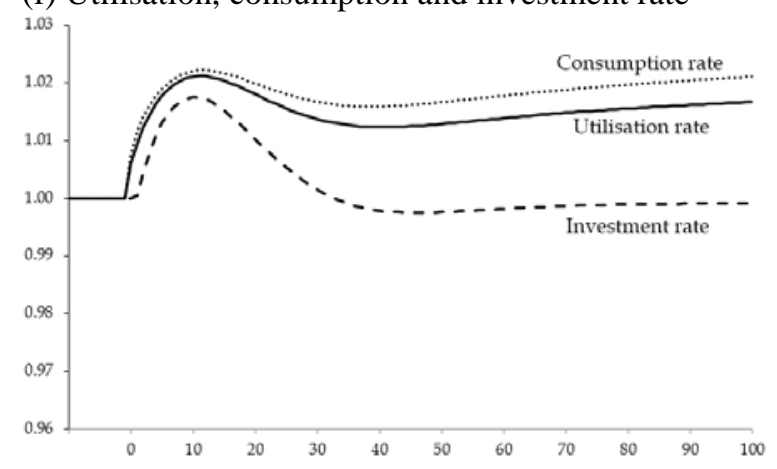

(h) Rate of retained profits and loans-to-output ratio

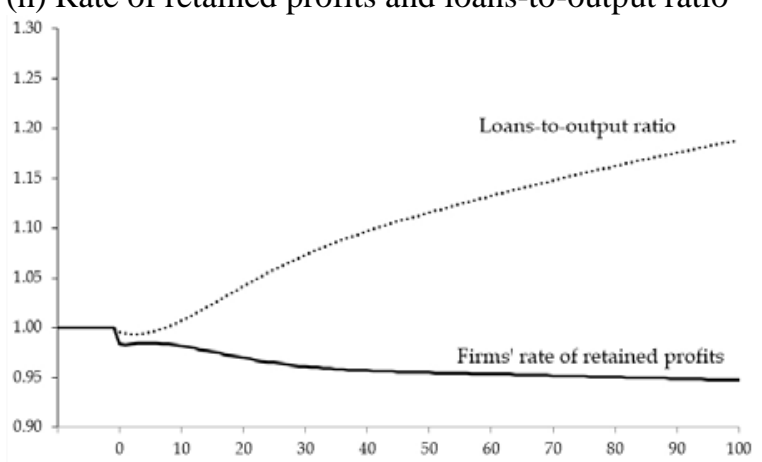


Figure 2. Effects of an increase in the exogenous component of the low-skilled workers' wage share, Case II

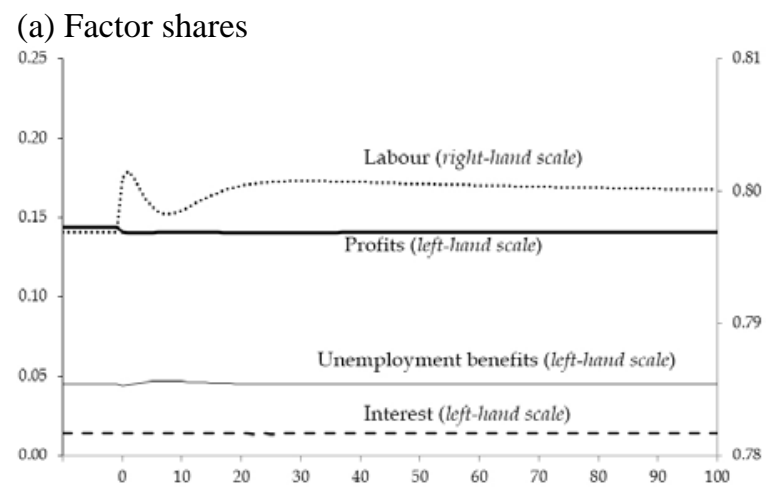

(b) Absolute contribution to inequality

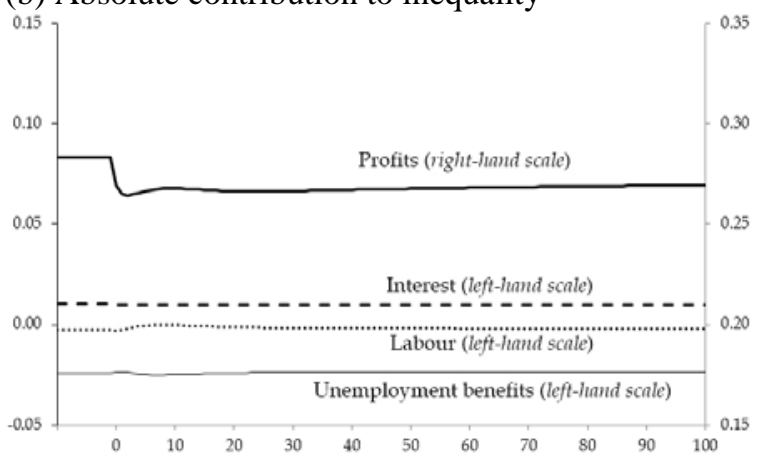

(c) Income ratios and deposit ratio

(d) Inequality indices
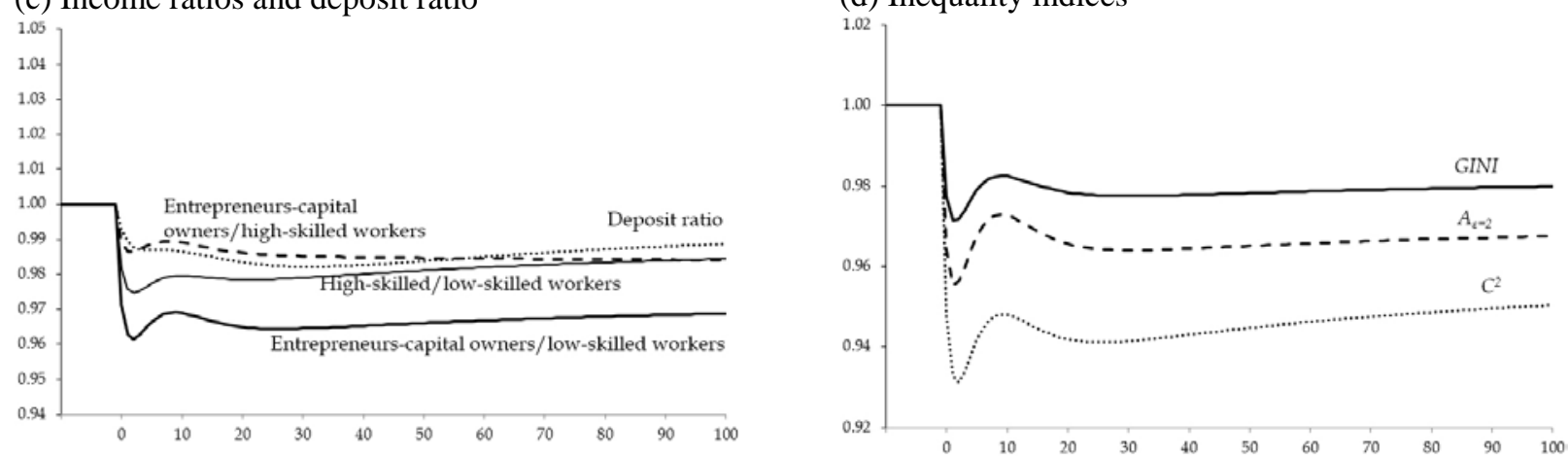

(e) Wage share and aggregate saving ratio

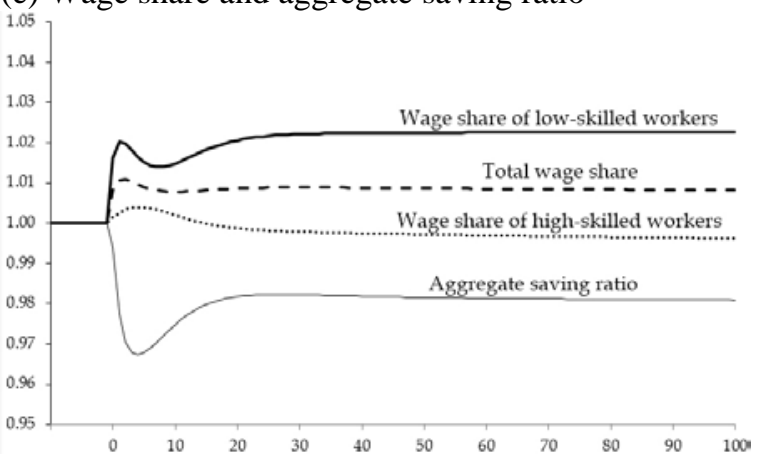

(f) Utilisation, consumption and investment rate

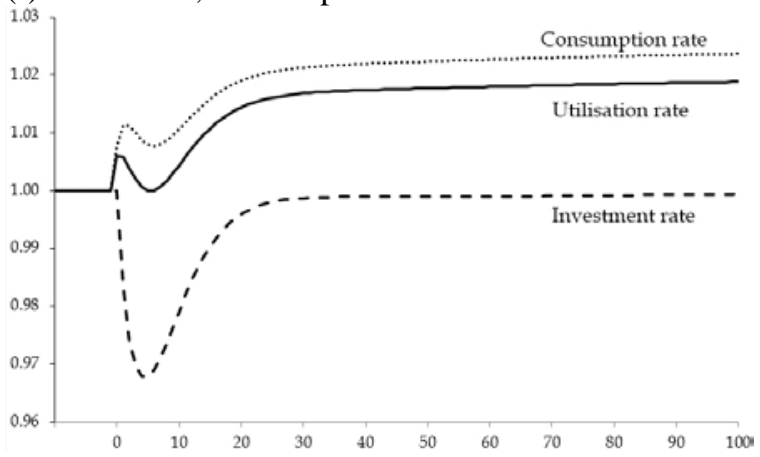

(g) Unemployment rates and growth rate of output

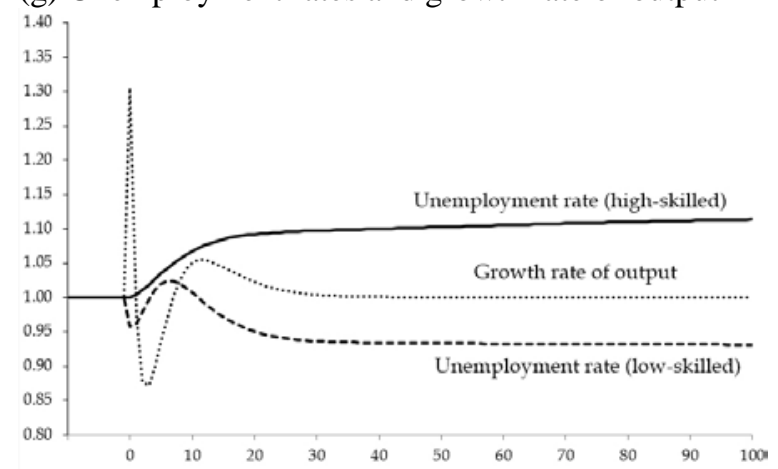

(h) Rate of retained profits and loans-to-output ratio

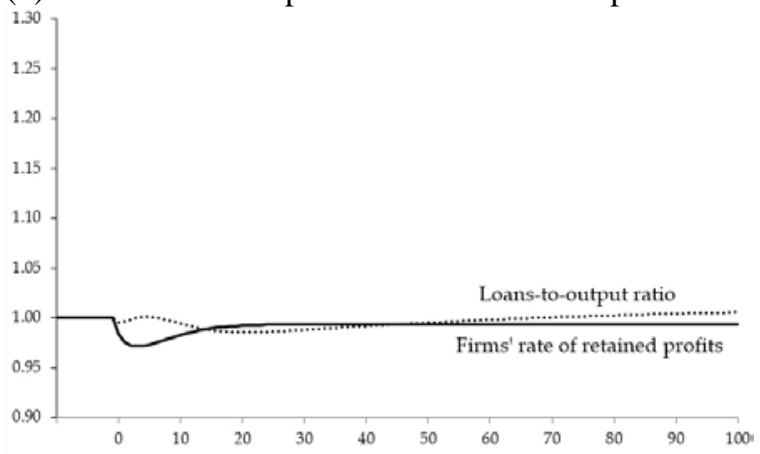


Figure 3. Effects of an increase in the dividend payout ratio, Case I

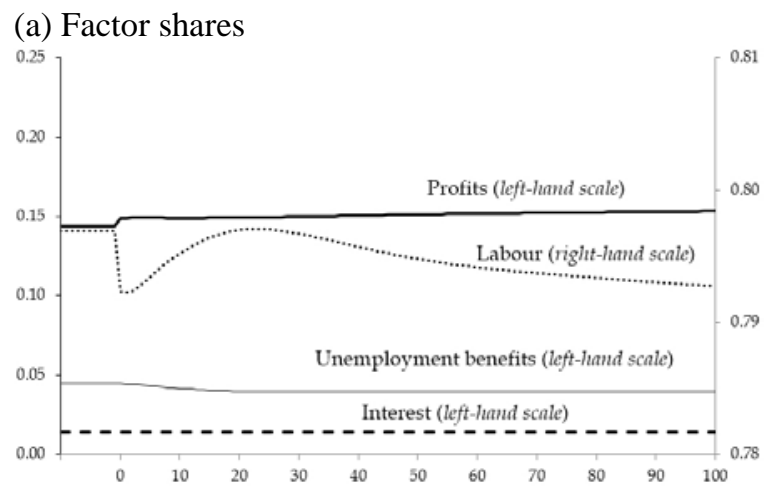

(b) Absolute contribution to inequality

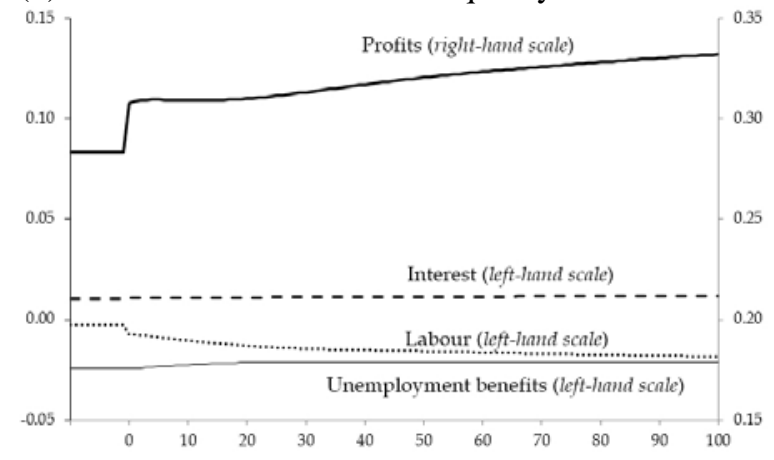

(c) Income ratios and deposit ratio

(d) Inequality indices
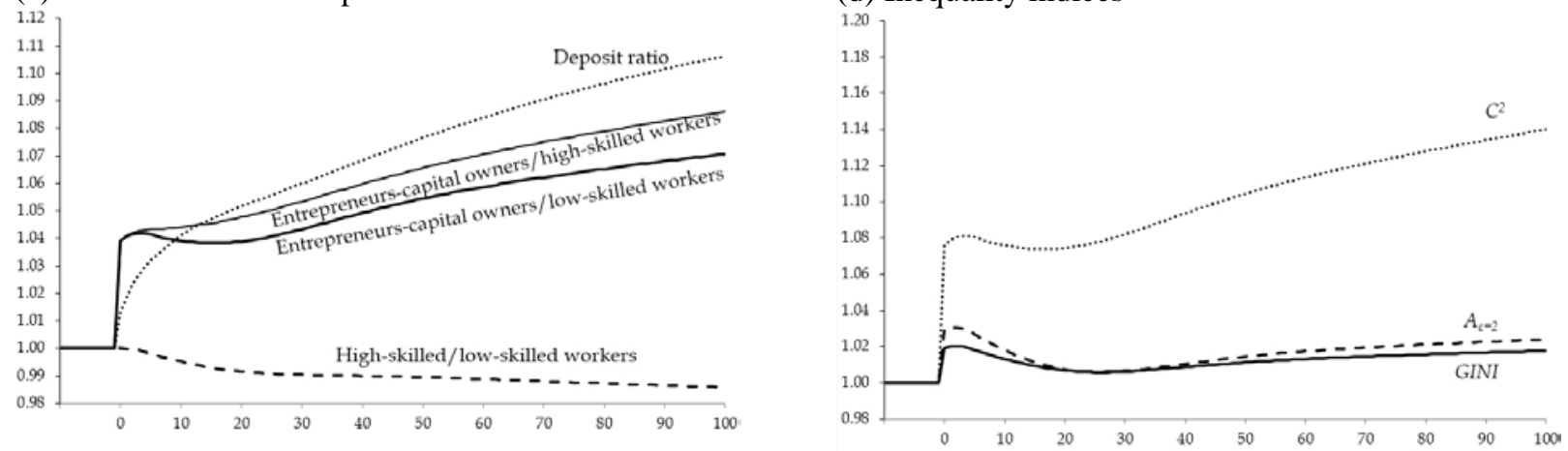

(e) Wage share and aggregate saving ratio

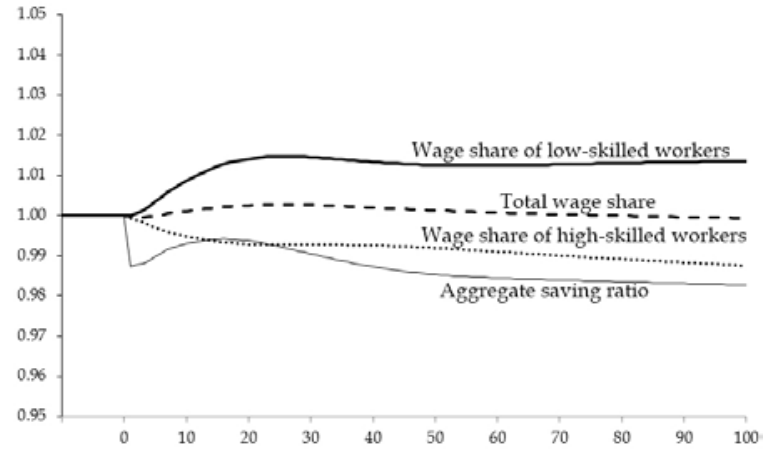

(f) Utilisation, consumption and investment rate

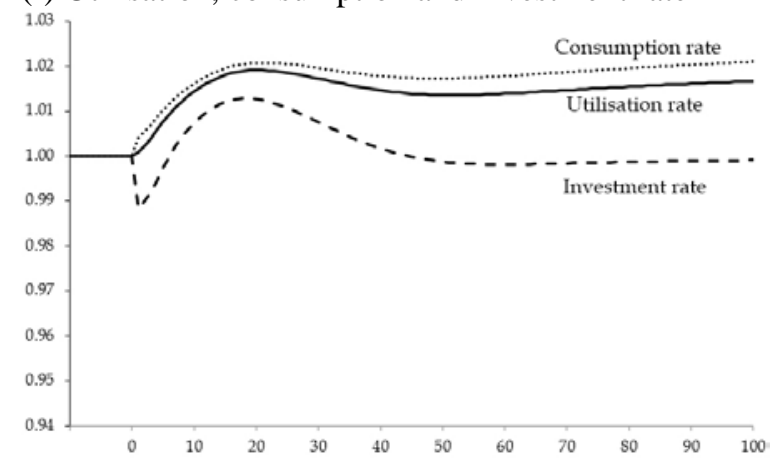

(g) Unemployment rates and growth rate of output

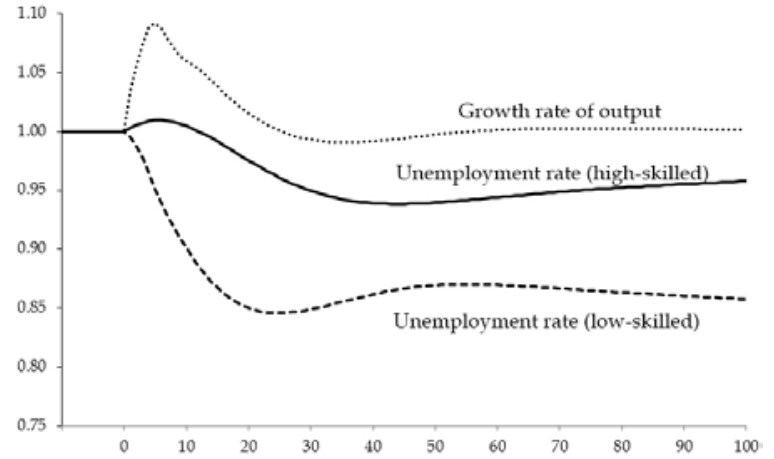

(h) Rate of retained profits and loans-to-output ratio

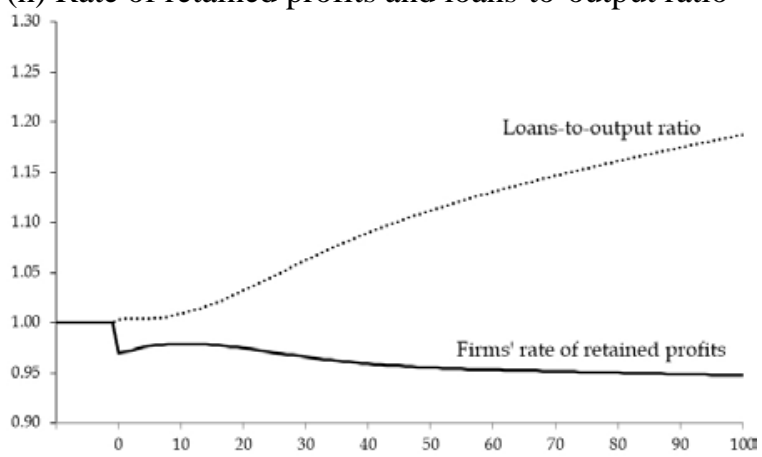


Figure 4. Effects of an increase in the dividend payout ratio, Case II

(a) Factor shares

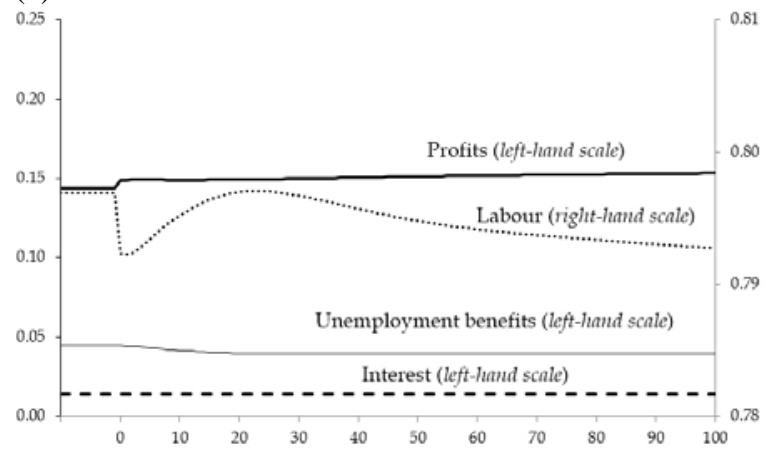

(c) Income ratios and deposit ratio

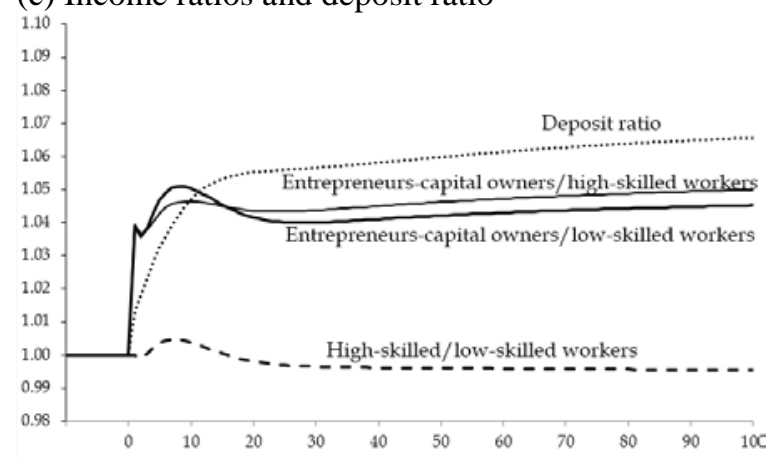

(e) Wage share and aggregate saving ratio

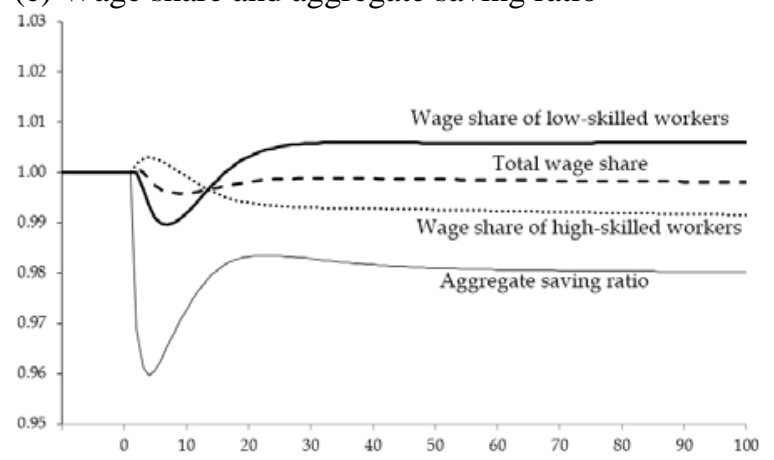

(g) Unemployment rates and growth rate of output

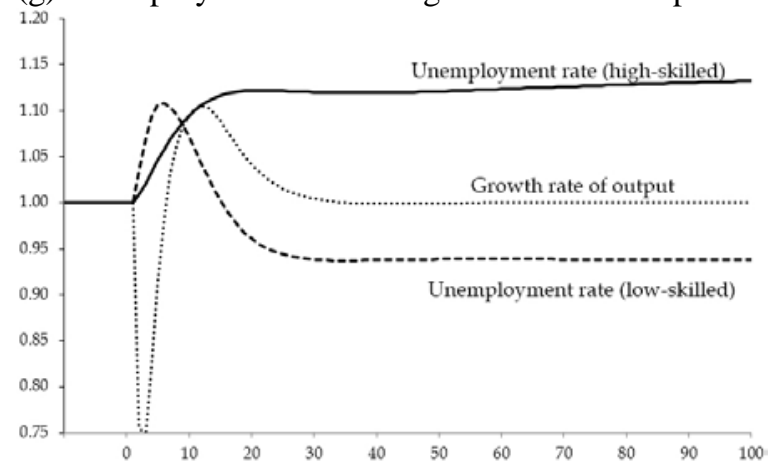

(b) Absolute contribution to inequality

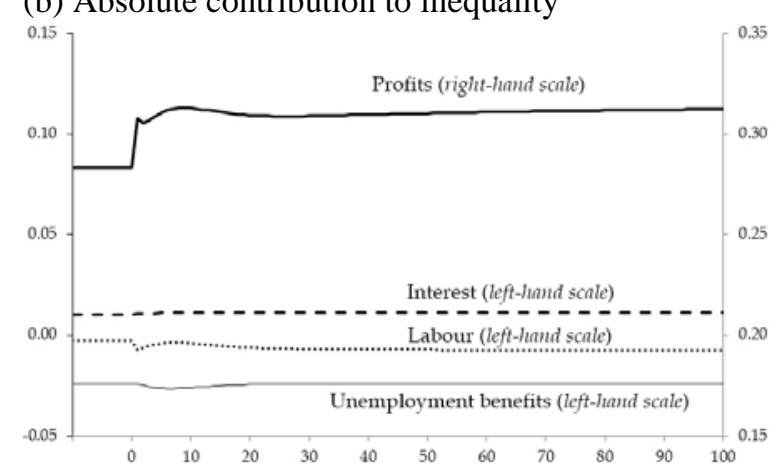

(d) Inequality indices

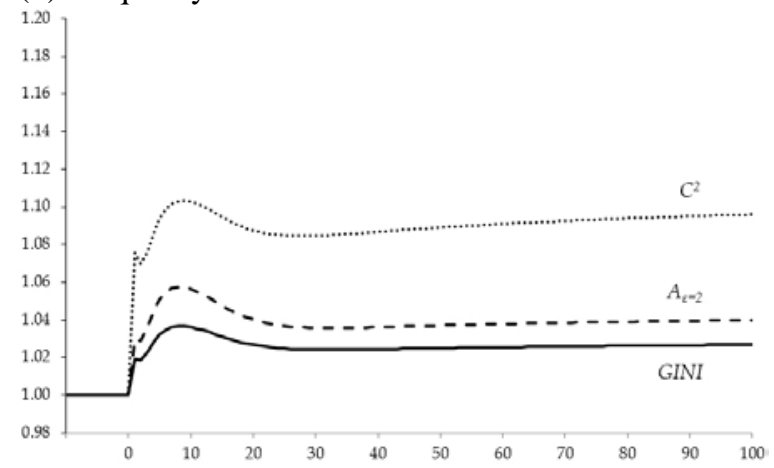

(f) Utilisation, consumption and investment rate

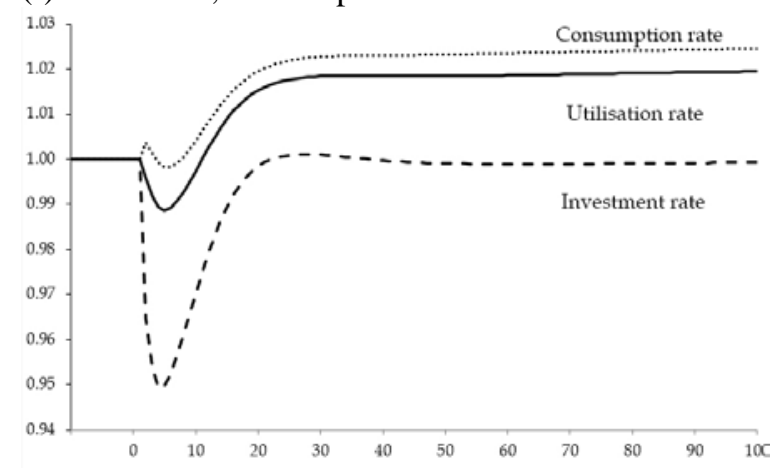

(h) Rate of retained profits and loans-to-output ratio

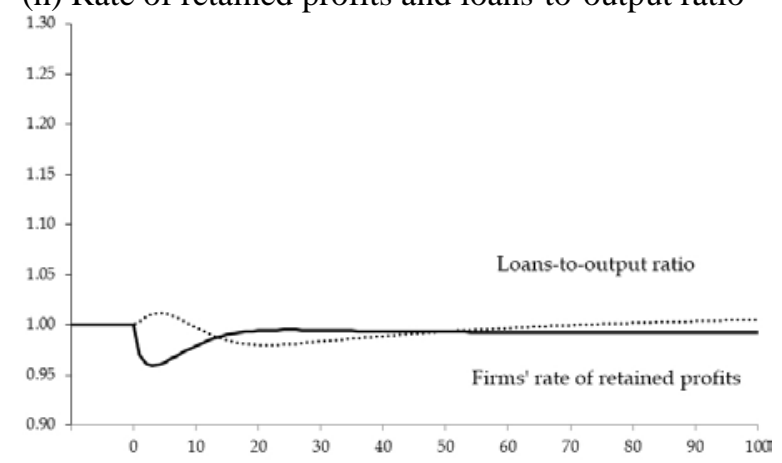


Appendix A: Values for parameters and exogenous variables in the simulation exercises

\begin{tabular}{ll}
\hline$N_{L}=550,000$ & $x=0.045$ \\
$N_{H}=400,000$ & $r_{M}=0.01$ \\
$N_{E}=50,000$ & $s p r=0.025$ \\
$N=1,000,000$ & $g_{\lambda}=0.02$ \\
$\tau_{W}=0.03$ & $w_{1}=0.24$ \\
$\tau_{F}=0.03$ & $m_{W}=1.6$ \\
$\xi=0.6$ & $\rho=0.3$ \\
$v=0.125$ & $h=(0.2 / \rho)+0.3$ \\
$c_{H E 1}=0.8$ & $d_{0}=-0.012$ \\
$c_{H E 2}=0.08$ & $d_{1}=0.5$ (Case I) \\
$c_{H U 1}=0.9$ & $d_{1}=1.5$ (Case II) \\
$c_{H U 2}=0.25$ & $d_{2}=0.03$ (Case I) \\
$c_{E 1}=0.6$ & $d_{2}=0.01$ (Case II) \\
$c_{E 2}=0.04$ & $w_{0}=0.34$ (before the wage shock) \\
$\lambda_{0}=0.56$ & $w_{0}=0.345$ (after the wage shock) \\
$\lambda_{1}=0.3$ & $s_{f}=0.66$ (before the dividend payout ratio shock) \\
$\lambda_{2}=0.3$ & $s_{f}=0.64$ (after the dividend payout ratio shock) \\
$\lambda_{3}=0.05$ & \\
\hline
\end{tabular}




\section{Appendix B: Steady-state values of key endogenous variables in the simulation exercises}

\begin{tabular}{|c|c|c|}
\hline Variable & Mathematical expression & Steady-state value \\
\hline Labour's share in total household income & {$\left[\left(1-\tau_{W}\right) \cdot\left(w_{L} \cdot N_{L E}+w_{H} \cdot N_{H E}\right)\right] / Y_{T}$} & 0.80 \\
\hline Unemployment benefits' share in total household income & $U B / Y_{T}$ & 0.05 \\
\hline Profits' share in total household income & $(D P+B P) / Y_{T}$ & 0.14 \\
\hline Interest's share in total household income & {$\left[r_{M} \cdot\left(M_{H E-1}+M_{H U-1}+M_{E-1}\right)\right] / Y_{T}$} & 0.01 \\
\hline Labour's absolute contribution to inequality & See equation $(64)$ & 0.00 \\
\hline Unemployment benefits' absolute contribution to inequality & See equation $(64)$ & -0.02 \\
\hline Profits' absolute contribution to inequality & See equation $(64)$ & 0.28 \\
\hline Interest's absolute contribution to inequality & See equation $(64)$ & 0.01 \\
\hline Income ratio: high-skilled to low-skilled workers & {$\left[\left(Y_{H E}+Y_{H U}\right) / N_{H}\right] /\left[\left(Y_{L E}+Y_{L U}\right) / N_{L}\right]$} & 1.61 \\
\hline Income ratio: enterpreneurs-capital owners to low-skilled workers & $Y H_{E} /\left[\left(Y_{L E}+Y_{L U}\right) / N_{L}\right]$ & 4.15 \\
\hline Income ratio: enterpreneurs-capital owners to high-skilled workers & $Y H_{E} /\left[\left(Y_{H E}+Y_{H U}\right) / N_{H}\right]$ & 2.58 \\
\hline Deposit ratio: enterpreneurs-capital owners to high-skilled workers & $\left(M_{E} / N_{E}\right) /\left[\left(M_{H E}+M_{H U}\right) / N_{H}\right]$ & 3.56 \\
\hline Gini coefficient & See equation (58) & 0.22 \\
\hline Squared coefficient of variation & See equation (59) & 0.27 \\
\hline Atkinson index $(\varepsilon=2)$ & See equation $(60)$ & 0.15 \\
\hline Wage share of low-skilled workers & $\left(w_{L} \cdot N_{L E}\right) / Y$ & 0.31 \\
\hline Wage share of high-skilled workers & $\left(w_{H} \cdot N_{H E}\right) / Y$ & 0.37 \\
\hline Total wage share & $\left(w_{L} \cdot N_{L E}+w_{H} \cdot N_{H E}\right) / Y$ & 0.68 \\
\hline Aggregate saving ratio & $(Y-C) / Y$ & 0.20 \\
\hline Investment rate & $I / K$ & 0.02 \\
\hline Consumption rate & $C / K$ & 0.08 \\
\hline Capacity utilisation rate & See equation (42) & 0.79 \\
\hline Unemployment rate of low-skilled workers & See equation (5) & 0.12 \\
\hline Unemployment rate of high-skilled workers & See equation (18) & 0.07 \\
\hline Growth rate of output & $\left(Y-Y_{-1}\right) / Y_{-1}$ & 0.02 \\
\hline Firms' rate of retained profits & $R P / K$ & 0.016 \\
\hline Loans-to-output ratio & $L / Y$ & 1.54 \\
\hline Total unemployment rate of workers & $\left(N_{L U}+N_{H U}\right) /\left(N_{L}+N_{H}\right)$ & 0.10 \\
\hline Firms' rate of profit & $\mathrm{TP} / \mathrm{K}$ & 0.024 \\
\hline Firms' leverage ratio & $L / K$ & 0.15 \\
\hline Rate of return on equity & See equation (27) & 0.16 \\
\hline
\end{tabular}

